\title{
Quality assessment of replacement stones for the Cologne Cathedral: mineralogical and petrophysical requirements
}

\author{
B. Graue $\cdot$ S. Siegesmund $\cdot$ B. Middendorf
}

Received: 4 March 2011 / Accepted: 22 April 2011/Published online: 19 May 2011

(C) The Author(s) 2011. This article is published with open access at Springerlink.com

\begin{abstract}
Owing to its long building history, different types of building stones comprised the construction of the Cologne Cathedral. Severe damage is observed on the different stones, e.g., sandstones, carbonate, and volcanic rocks, especially when the different stone materials neighbor the medieval "Drachenfels trachyte" from the "Siebengebirge". The question arises, "Is the insufficient compatibility of the implemented building materials causatively related to the strong decay of the Drachenfels trachyte?" The present investigations focus on the petrography and mineralogical composition of eight different stones from the Cologne Cathedral. Petrophysical data, i.e., phase content, moisture and thermal characteristics as well as strength properties are determined and discussed in correlation to each other, showing that not only in terms of lithology great differences exist, but also the petrophysical properties strongly diverge. The ascertained parameters are discussed in view of the deterioration behavior and decay mechanisms of the different stones. To evaluate the compatibility of original, replacement and modern building materials, the properties of the investigated stones are compared to those of Drachenfels trachyte by means of constraints given in the literature. Besides optical properties, petrophysical criteria are also defined as well as strength values. It could be shown that primarily
\end{abstract}

B. Graue $(\varangle) \cdot$ S. Siegesmund

Department of Structural Geology and Geodynamics,

Geoscience Center of the University of Goettingen,

Goldschmidtstr. 3, 37077 Goettingen, Germany

e-mail: info@graue.org

B. Middendorf

Faculty of Architecture and Civil Engineering,

Department of Building Materials, TU Dortmund University,

August-Schmidt-Str. 8, 44227 Dortmund, Germany moisture properties, i.e., capillary and sorptive water uptake, water saturation, drying processes and moisture dilatation can be addressed to the deterioration processes.

Keywords Stone decay - Cologne Cathedral . Compatibility of building materials .

Requirements for replacement stones

\section{Introduction}

The Cologne Cathedral is one of the most important sacral, political, and cultural monuments in Northern Europe. This Gothic building has a unique position in an art historical context. The cathedral has a very long construction history in which different types of stone materials were used (Figs. 1, 2). Since the Roman period the Drachenfels trachyte from the quarries of the Siebengebirge was mainly used as natural building stone for construction in Cologne. The Rhine River provided an excellent means of transporting good stone material from quarries along the Rhine and connecting rivers (Wolff 2004). In Fig. 2, the lithological survey map illustrates that the topic of stone procurement was very important for the over 600-year construction period of the Cologne Cathedral. The increasing deterioration of the building materials from the historic and more recent construction history has endangered the structure of the cathedral. Construction scaffolding, which is always present as a permanent installation indicates that preservation work is continuous at the Cologne Cathedral.

The increasing emission of pollutants in our industrial society has considerably accelerated the process of weathering of building materials (for discussion, see Siegesmund and Snethlage 2011). Generally, the 
Fig. 1 South elevation of the Cologne Cathedral

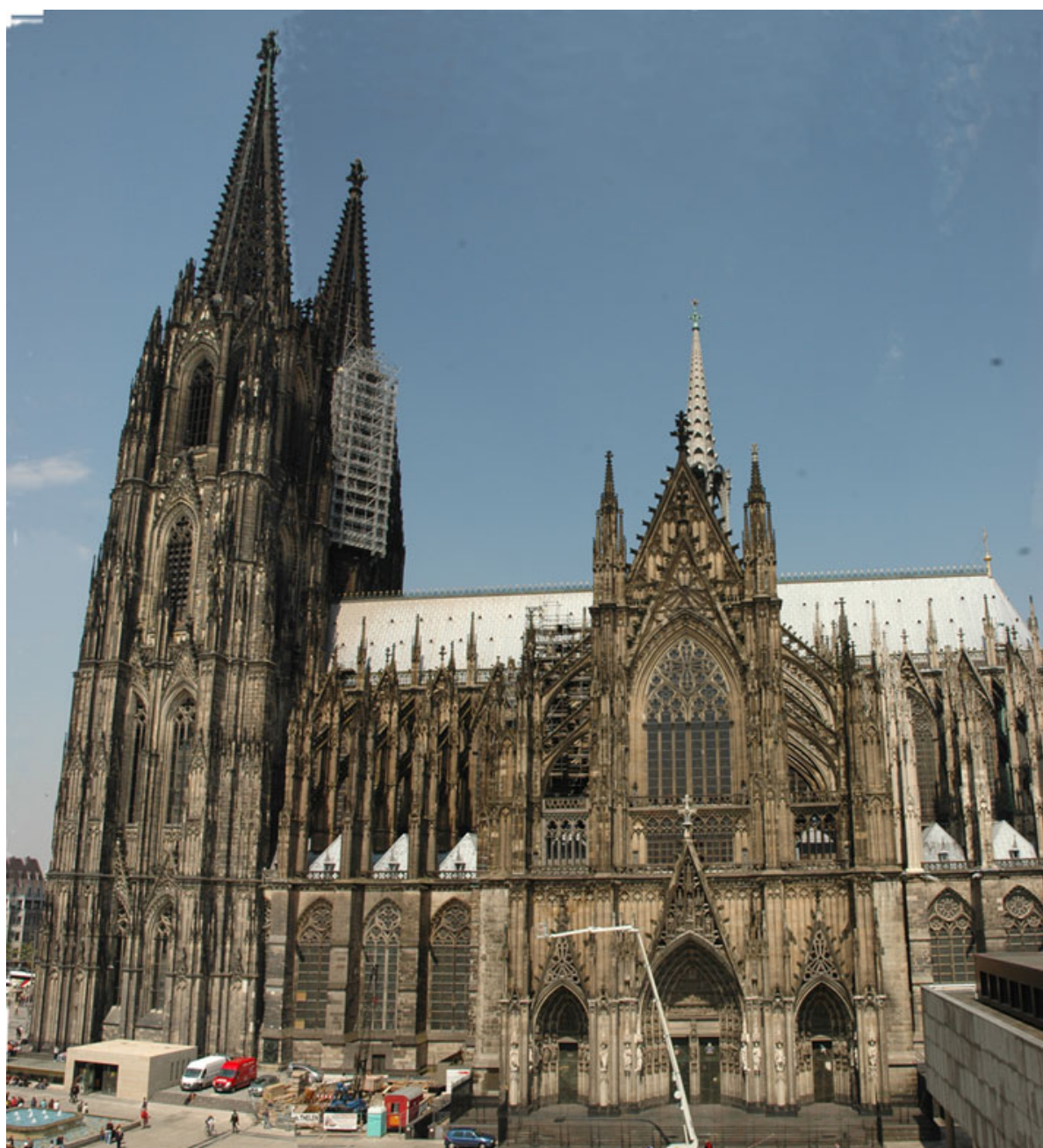

assumption has been that acid-forming sulphur compounds penetrate into the microstructure of the stone and then become neutralized depending upon the rocks' composition. These become concentrated as sulphate-rich salts (especially gypsum enrichment) and are responsible for the many damages observable (e.g., Knetsch 1952; Kraus 1985a; Kraus and Jasmund 1981). Cologne is a major city with approximately one million inhabitants. Urban mobile pollution sources, such as automobiles, trucks, railway, etc., are the main contributors of air pollution in the city today. Although the emission levels have dropped in the last 30 years, dust pollution is still a major problem. The observed values of air pollution can be correlated with the increased number of chronic respiratory diseases (Wolf 2002). Török et al. (2010) investigated a series of samples from the Cologne Cathedral, which were collected at about $30 \mathrm{~m}$ above the ground from the external walls. Very high concentrations of lead (736 ppm) could be detected in dust samples collected from different areas. The lead also accumulates in the black crust, especially close to the limestone crust interface. This indicates that either the crust exhibits signals of past pollution levels or lead is being mobilized from the surface to deeper zones. Even though the $\mathrm{SO}_{2}$ content decreased in the atmosphere, the situation in many industrial countries can be characterized as a "multi-pollutant" setting $\left(\mathrm{CO}_{2}, \mathrm{NO}_{\mathrm{x}}, \mathrm{VOC}\right.$ (volatile organic compounds), dust, etc.).

In the coming years, upcoming restoration measures should also demand the analysis of the natural building stones, especially those selected as future replacement materials. Not only should the weathering resistance be investigated but also the material compatibilities need to be analyzed. Recent observations at the Cologne Cathedral lead to the assumption that the use of different building materials, i.e., the historic and more recent replacement stones, causes a negative interference in terms of their deterioration and is of particular importance (Kraus 1985a; Wolff 1992; von Plehwe-Leisen et al. 2007). The main question arises, "Can the insufficient compatibility of the used building materials be causatively related to the strong deterioration of the Drachenfels trachyte?" Owing to the fact that the Drachenfels trachyte quarry has been protected 
Fig. 2 Lithological map of the south elevation of the Cologne Cathedral (Windscheid (2004) after Wolff and Luckat 1973)

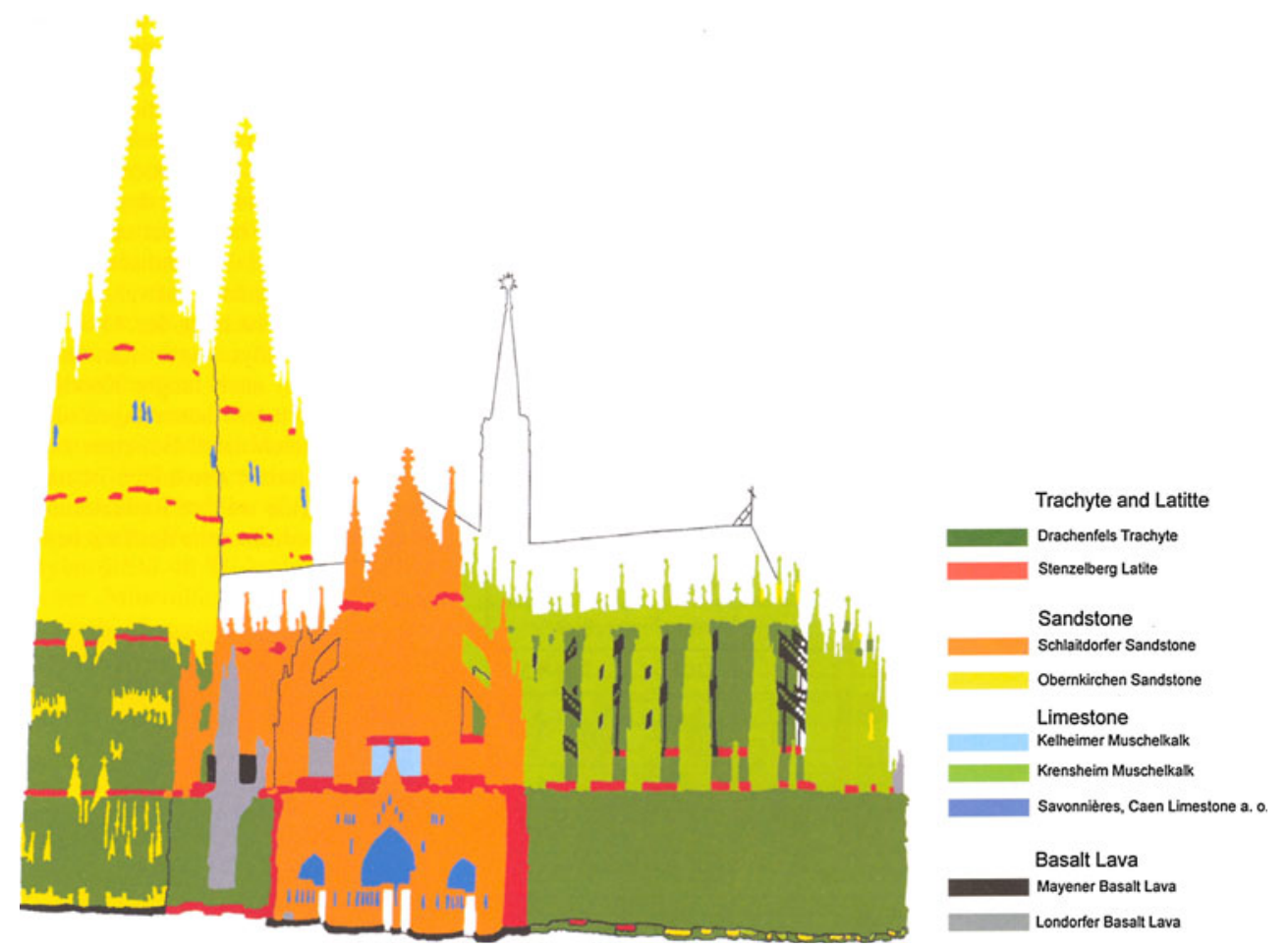

by conservation since 1922 , no original material is available, and the search for adequate replacement stones is still under discussion. Figure 2 documents that the medieval part of the cathedral consists of Drachenfels trachyte, whereas in later periods different stone types were used for construction and repair purposes.

Since the middle of the nineteenth century, the building stones of the Cologne Cathedral and their deterioration behavior have been the subject of scientific scrutiny. Starting with the observation of an ongoing decay of the building's structure, the aim of these investigations has always been the search for suitable replacement stone material.

In this study, the mineralogical and petrophysical properties of the used rock types from the Cologne Cathedral are investigated. On the basis of these investigations, the compatibility between the different stone types will be reflected. Therefore, it is necessary to determine the porosity and the pore size distribution (PSD), the water absorption and the capillary loading behavior, the saturation coefficient, moisture and thermal expansion as well as the mechanical rock properties. In addition, the material should have similar optical properties (e.g., color, décor, etc.).

\section{Building history and the employment of replacement stones}

Construction of the Cologne Cathedral started in 1248. The medieval part of the cathedral was built from Drachenfels trachyte from the nearby quarry in the Siebengebirge. At the beginning of the sixteenth century, the construction was halted and recommenced at the beginning of the nineteenth century. At that time, the Drachenfels trachyte was no longer available.

The first replacement material used for the resumption of construction work on the cathedral consisted of local stone material available from the Siebengebirge. Initial renovations were carried out with latite from the "Stenzelberg" and a few other materials from the quarries of the Siebengebirge. In the middle of the nineteenth century, the second construction phase used sandstone from "Schlaitdorf", southern Germany. Later on, when the railway connection between Cologne and Minden was built, the "Obernkirchner" sandstone from Lower Saxony could be transported. The third construction phase started in 1918 and lasted until the beginning of WWII, where the "Krensheimer Muschelkalk" was the characteristically used stone. In the 1950s, the decay resistant basalt lava from "Londorf" was implemented. Presently, the trachyte from "Montemerlo" (Italy) is used to replace the deteriorated Drachenfels trachyte; in addition, the sandstone from "Bozanov" (Czech Republic) is used to replace the weathered Schlaitdorfer sandstone (Table 1) (Scheuren 2004; Schumacher 2004).

Since 1820, when the construction work and first repair work resumed, a number of investigations for suitable building materials for the Cologne Cathedral already existed. A. von Lasaulx (1882) broached the subject of 
Table 1 Main construction phases and building material used at the Cologne Cathedral (Scheuren 2004, Schumacher 2004)

\begin{tabular}{lll}
\hline Construction phase & Period & Building material \\
\hline First construction phase & $1248-1520 / 1530$ & Drachenfels trachyte \\
End of construction of the medieval cathedral & 1530 & \\
Resumption of the construction work, first repairs & $1820-1830$ & Wolkenburger latite, Stenzelberg latite, Heilbronner sandstone \\
Second construction phase $>$ sandstone period $<$ & $1842-1860 \mathrm{~s}$ & $\begin{array}{l}\text { Schlaitdorfer sandstone } \\
\text { Obernkirchner sandstone }\end{array}$ \\
Third construction phase $>$ limestone period $<$ & From 1864 onward & $\begin{array}{l}\text { Krensheimer Muschelkalk (1918-1940) } \\
\text { Fourth construction phase }\end{array}$ \\
& From 1945 onward & Caen, Savonnières limestone \\
& Since 1952 & Londorfer basalt lava \\
& Since 2001 & Bozanov sandstone \\
& Since 2005 & Montemerlo trachyte \\
\hline
\end{tabular}

weathering resistance in the implementation of building stones. During the period under the supervision of master builder, Hertel (1903-1927), a first systematic survey of the deterioration behavior of the building stones of the Cologne Cathedral took place (Hertel 1927). Besides the works of Kaiser (1910a, 1910b, 1910c), Hirschwald (1910; 1912) was substantially involved in the development of constructional investigations and the analyses of building stones. He also laid the foundation for geoscientific analyses in the preservation of cultural monuments.

Grün $(1931,1933)$ showed that the condition of the different building stones at the Cologne Cathedral varied widely (Grün 1931, 1933; Rathgen and Koch 1934). The mortars used were considered as a potential source for the deterioration and Grün (1931) explicitly addressed the environmental influences as deterioration factors.

Beginning with Knetsch (1952) emphasis was placed on the geological and climatic context. The influence of air pollutants and especially of flue gas on the deterioration of natural building stones was detected in a program in the 1970s and potential preventive conservation treatments were tested (Luckat 1973a, 1974, 1975, 1977, 1984; Wolff and Luckat 1973; Wolff 1986; Wolff et al. 1988). Efes and Lühr (1976) accentuated the influence of environmental pollutants as a significant factor for the stone decay. Further studies dealt with the different deterioration processes in several natural building stones from the Cologne Cathedral (Kraus 1980; Kraus 1985a, 1985b; Kraus and Jasmund 1981; Mirwald et al. 1987; Knacke-Loy 1988; 1989). Wolff (1992) first mentioned the negative interferences between the Schlaitdorfer sandstone and Londorfer basalt lava, which mainly deteriorates the sandstone and as a result of this the neo-Gothic building structure. This raises the question again about which stone material with comparable mineralogical, physical, and technical properties is suitable as a replacement material for the Cologne Cathedral. The preservation of the Cologne Cathedral is determined by the appropriate choice of a replacement stone as well as the development of conservation treatments and materials. Potential solutions were drawn for the conservation of the Drachenfels trachyte (Dombauhütte Köln 2006; von Plehwe-Leisen et al. 2007). Until now, the discussion about the preservation and conservation of the stone materials used at the Cologne Cathedral is still in progress.

\section{Decay phenomena}

The different building stones of the Cologne Cathedral show a large variation of weathering phenomena. On a representative survey area (Fig. 3a, b), the building material and the deterioration phenomena have been mapped in accordance with the classification by Fitzner et al. (1995) and Siedel et al. (2011). Typical decay phenomena consisting of surface deterioration, back-weathering, scaling, structural disintegration, flaking and depositions are illustrated in Figs. 4 and 5. The individual deterioration phenomena are assigned to the different building stones and described in detail.

The detailed map of Fig. 3 shows a section of the northern pillar of the North Tower, i.e., the medieval part built with Drachenfels trachyte and the modern construction phase from the nineteenth century, when Obernkirchner sandstone was employed. The amount of Drachenfels trachyte used in the mapped area is about $71 \%$, Obernkirchner sandstone is used approximately $27 \%$ as well as a minor percentage $(\sim 2 \%)$ of Schlaitdorfer sandstone (Fig. 3a). While the complete surfaces of all stones show a more or less distinctive deposition of dust and aerosols, microbiological growth can only be observed in the lower areas at the cornice. The localizations of the deterioration phenomena are shown in the map presented in Fig. 3. 
Fig. 3 Map illustrating the northern pillar of the North Tower at the Cologne Cathedral. a Stone distribution: $71 \%$ Drachenfels trachyte (red), 27\% Obernkirchner sandstone (beige), $2 \%$ Schlaitdorfer sandstone (yellow). Joints: mortar joints (brown), lead joints (light blue), slate plates (pink). b The main deterioration phenomena are: surface deterioration (light blue), flaking (green), backweathering (orange), scaling (pink), cracks (red), breakouts (dark turquoise), crumbling (brown), weathered-out sanidines (dark blue), microbiological growth (dark red), gypsum crusts (light green) (a)

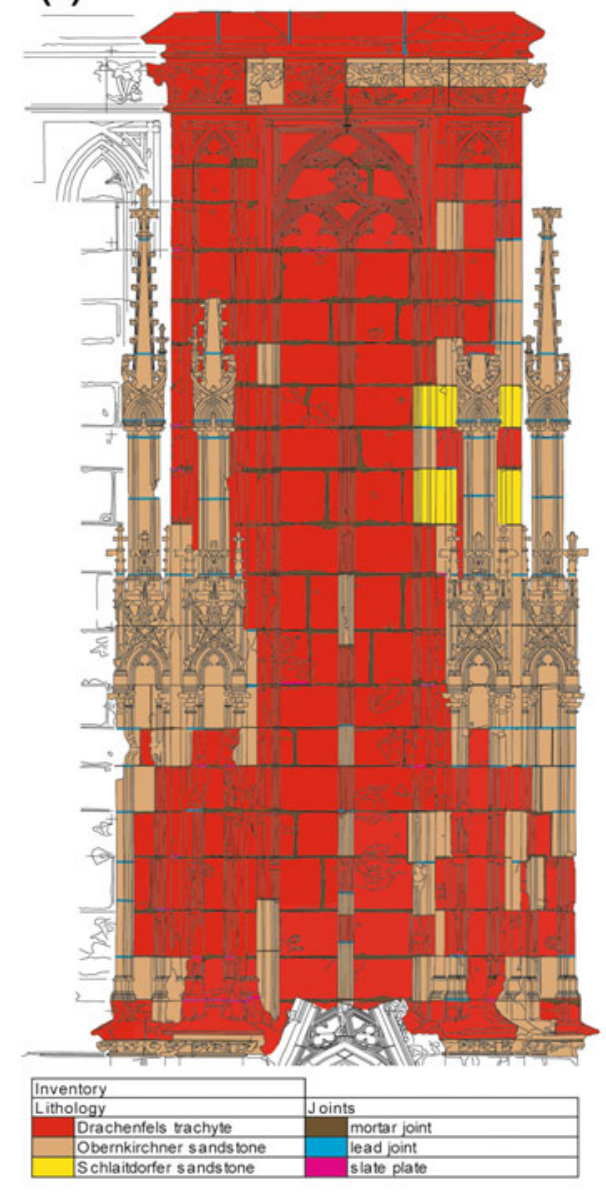

(b)

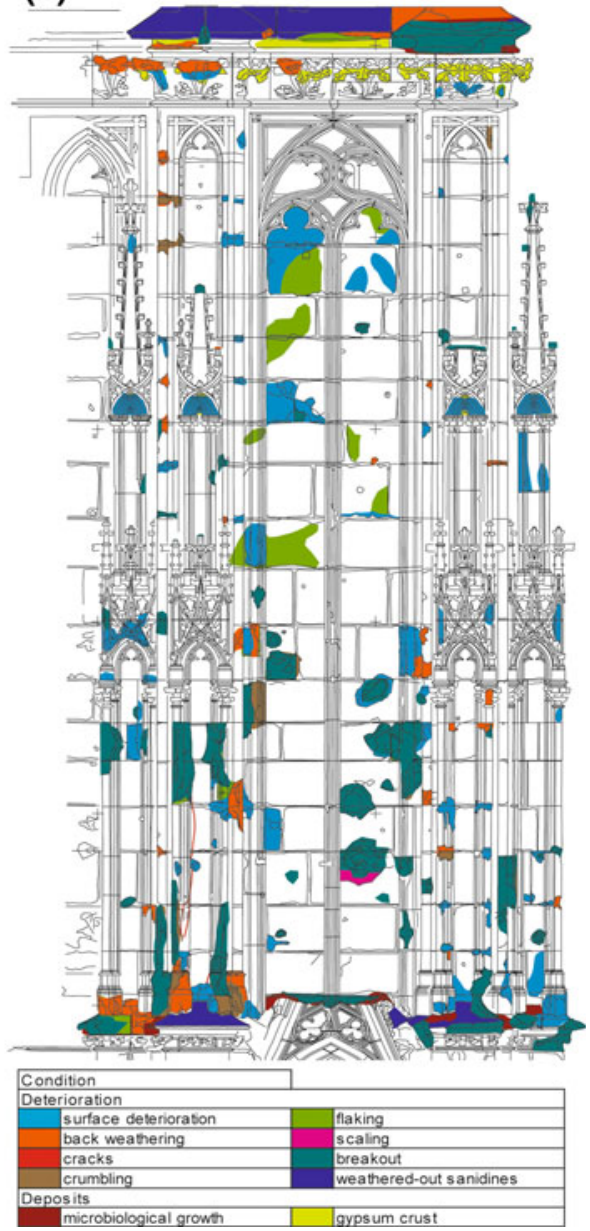

The main deterioration phenomena observable in the Drachenfels trachyte are surface deterioration and backweathering (Fig. 4a-c) coexisting with flaking (Fig. 4f) and structural disintegration to crumbling (Fig. 4d). Backweathered areas often display stronger further decay in terms of microcracks, crumbling to total collapse. Scaling is observable (Fig. 4b) and very often shows a granular disintegrated zone on the reverse side. Formation of cracks and fissures may also propagate many centimeters in depth into the stone. Drachenfels trachyte is characterized by large crystals of sanidines up to $7 \mathrm{~cm}$ in length. These may cause a different weathering behavior between the matrix and the phenocrysts. In the mapped area, the sanidines are weathered-out (Fig. 4g), but only in the areas of the cornices. The weathering behavior of the building stones is also controlled by the rock fabric. In the Drachenfels trachyte, the deterioration is more intense when the magmatic foliation, defined by the preferred orientation of sanidines, is parallel to the visible surface of the building stone (Fig. 4e). A number of breakouts can be observed in the Drachenfels trachyte, which are a result of the mechanical impact of bombing during WW II. von Plehwe-Leisen et al.
(2007) have reported that flaking and scaling is often observed. The flaking can occur in a very pronounced fashion, which eventually leads to structural disintegration and total fabric collapse. There are strong indications that the decay phenomenon in the Drachenfels trachyte is especially critical in the direct neighborhood of carbonate replacement stones (Kraus 1985a; von Plehwe-Leisen et al. 2007). In many places, the decay starts from the joints, which is indicated by gypsum crusts, flaking and scaling (Fig. 5a).

In general, Obernkirchner sandstone is a very deterioration resistant stone material (Grimm 1990). In the area of the north tower the main deterioration phenomenon is the deposition of dust, forming grayish to black crusts as well as the formation of gypsum crusts in posterior areas (Fig. 5b). In some areas at the Cologne Cathedral, the Obernkirchner sandstone was painted to color adjust the stone to the Krensheimer Muschelkalk, which was used for reinstatement work in the 1930s. In connection with this paint layer, a surface parallel scaling of very thin scales (thickness of 1-2 mm) can be observed (Fig. 4a). Further severe damage is visible 

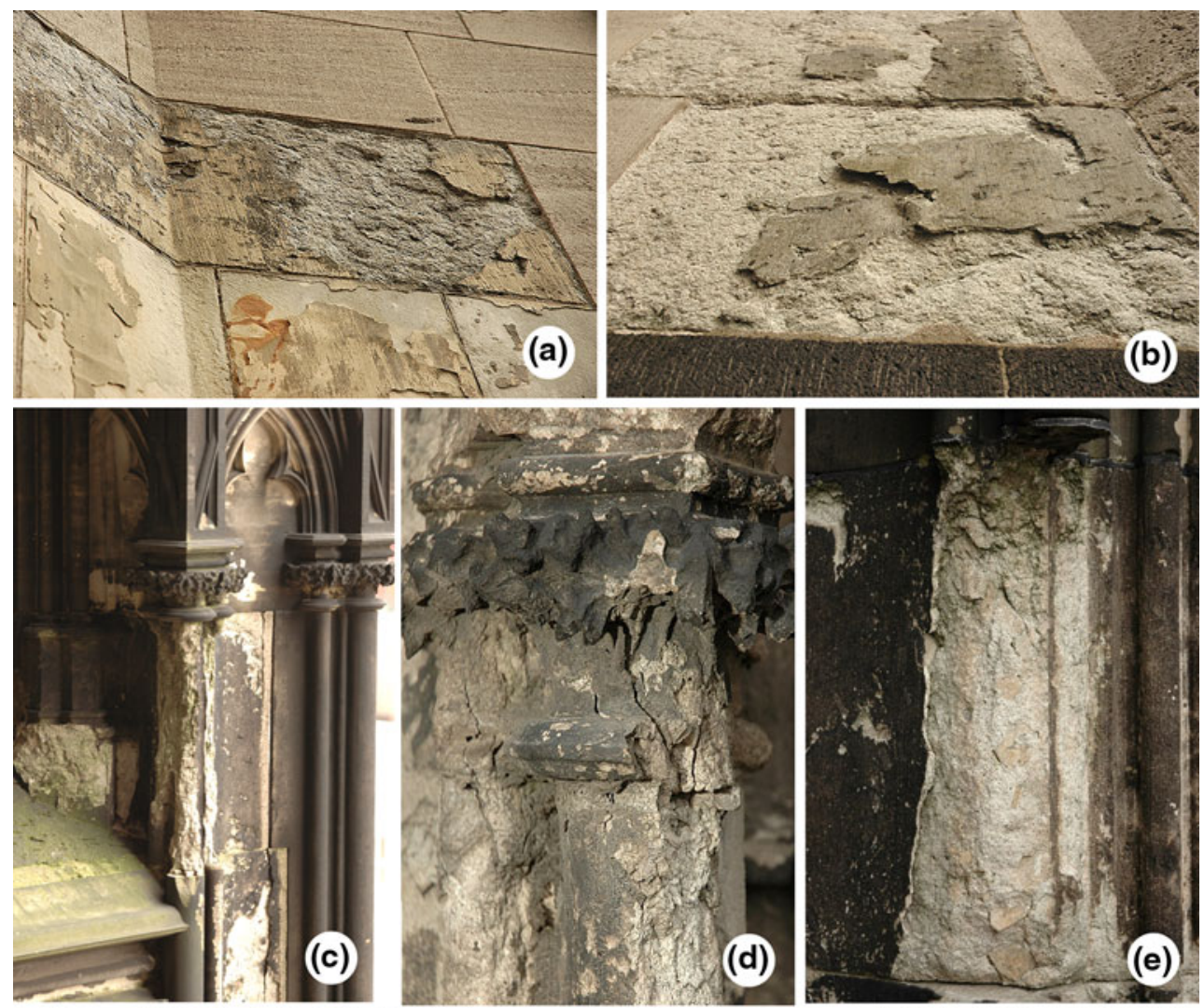

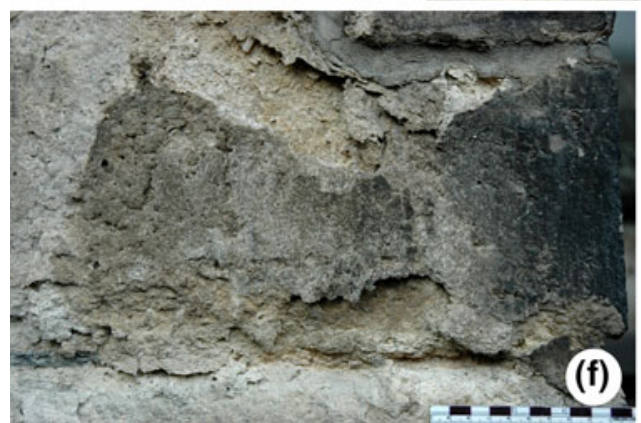

Fig. 4 Deterioration phenomena: a Overview: scaling and flaking of Drachenfels trachyte (center); scaling of Obernkirchner sandstone due to surface treatment (lower part); and Krensheimer Muschelkalk (upper part); b Drachenfels trachyte: scaling; c Drachenfels trachyte: back-weathering and structural disintegration (deteriorated pilaster

along joints, where the sandstone shows breakouts due to spalling, especially on the decorative parts, e.g., pilaster strips (Fig. 5c).

Schlaitdorfer sandstone is a very problematic stone at the Cologne Cathedral. Kraus (1985a) and Grimm (1990) report that this stone characteristically disintegrates. The carbonate cement (app. 14\%) causes the problem, whereby gypsum formation occurs that leads to massive scaling and flaking phenomena as well as granular disintegration. Moreover, another very typical deterioration phenomenon for the Schlaitdorfer sandstone is rounding and notching together with granular disintegration (Fig. 5d).

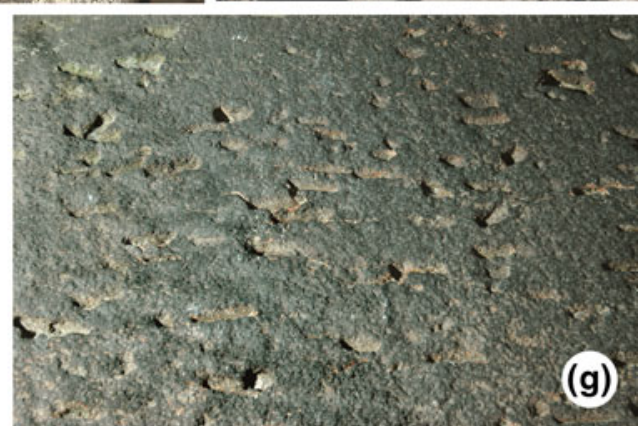

strip); d Drachenfels trachyte: pronounced decay in form of microcracks, crumbling to total collapse; e Drachenfels trachyte: pronounced surface deterioration due to the placement direction with surface planar sanidines; f Drachenfels trachyte: flaking; g Drachenfels trachyte: weathering out of sanidines

At present little is known about the deterioration behavior of the Montemerlo trachyte at the Cologne Cathedral, since this stone has only been implemented in recent years. Very often intensive orange-brown discoloration of the Montemerlo trachyte can be observed when it is used as a replacement stone. These iron discolorations have a negative aesthetic effect, but no structural impact. However, Lazzarini et al. (2008) report exfoliation and flaking, powdering and alveolic weathering for the Montemerlo trachyte.

Stenzelberg latite and Londorfer basalt lava are very resistant against weathering. Due to the high porosity, the 

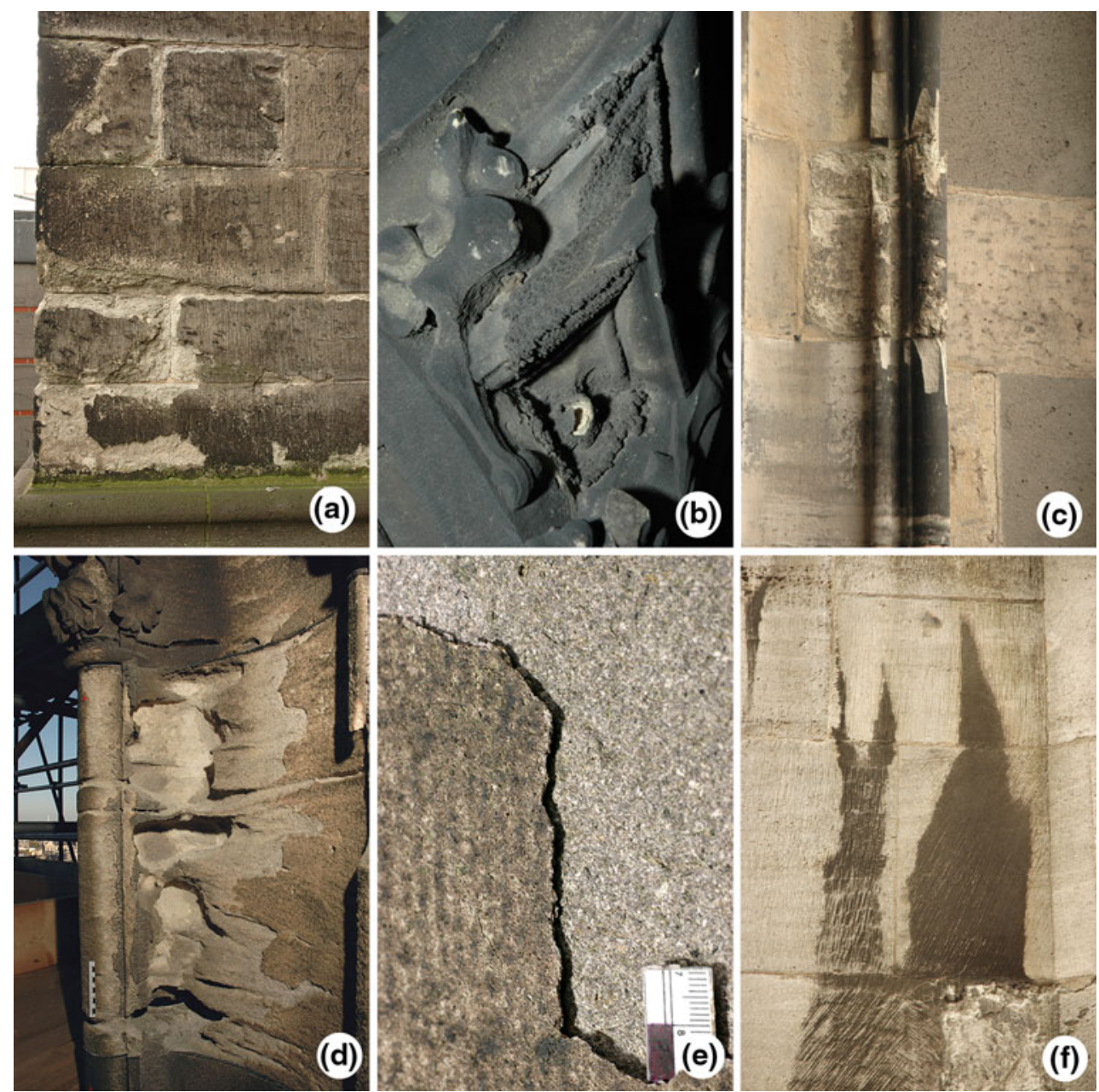

Fig. 5 Deterioration phenomena: a Drachenfels trachyte: deterioration starting from the joint; b Obernkirchner sandstone: black dirt and gypsum crusts; c Obernkirchner sandstone: breakouts due to spalling

Londorfer basalt lava is susceptible to microbiological action. The main deterioration phenomenon of Stenzelberg latite is a typical formation of scales with a thickness of 2-3 mm (Fig. 5e). Furthermore, Grimm (1990) observed exfoliation and contour-scaling, granular disintegration into grus as well as powder, and breakout of mafic mineral nests.

Bozanov sandstone shows spalling along edges when mounted, which is problematic for masonry works. Přikryl et al. (2010) reported on granular disintegration, scaling, flaking, crust formation, as well as blistering, fracturing, salt efflorescence and alveoli formation for the mediumgrained Bozanov sandstone.

In principal, the Krensheimer Muschelkalk is a deterioration resistant stone. This carbonate building stone shows massive gypsum crust formations as a result of acid rain (Fig. 5f). This is visible in rain-protected areas, whereas on surfaces exposed to rain, solution phenomena can be observed, e.g., microkarst. In these situations, the blocks along joints; d Schlaitdorfer sandstone: scaling, granular disintegration to sand and relief due to rounding and notching; e Stenzelberg latite: scaling; f Krensheimer Muschelkalk: black gypsum crusts

express a surface roughness and it leads to a loss of shape or form in detailed and decorative figural areas.

Joints are filled primarily with lime mortar, which often have inserted slate plates. These are randomly visible due to the back-weathered mortar. The present findings indicate that these slate plates are used to cover the entire contact surface of the building stones (Nussbaum and Lepsky 2010). The majority of the joints have been redone several times with modern mortars during the different restoration phases.

\section{Building stones of the Cologne Cathedral}

\section{Petrography}

The Drachenfels trachyte is a light gray, partially pale yellowish or reddish, porous, porphyritic trachyte with phenocrysts of sanidine up to $7 \mathrm{~cm}$ in size. The phenocrysts 
can show a preferred orientation in the matrix and traces a magmatic foliation, which indicates the former flow direction of the magma. According to Grimm (1990), the rock comprises $50 \%$ sanidine, $24 \%$ plagioclase, $13 \%$ quartz, $5 \%$ augite, $5 \%$ biotite, $2 \%$ ore and $1 \%$ apatite, zircon and sphene. The fabric of the Drachenfels trachyte is typical for volcanic rocks, which is characterized by phenocrysts enclosed in a fine-grained matrix. Feldspar and quartz comprise the groundmass (Fig. 6a). In places calcite occurs. Volcanic glass fractions are in parts altered to montmorillonite. More pyrite occurs in the groundmass than what is generally expected for trachytes. Furthermore, in some cavities pyrite and aggregates of pyrite-hematite (limonite?) can be found. The visible pore space comprises more than $10 \%$ (Grimm 1990).

The trachyte of Montemerlo shows an isotropic and homogenous fabric (Fig. 6b). In some cases, the rock exhibits a holocrystalline fabric with a weak parallel texture, where millimeter to centimeter large white feldspar crystals, black biotite and dark, prismatic amphiboles float in a gray, weakly yellow groundmass. Feldspar crystals can attain sizes ranging from 0.5 to $10 \mathrm{~mm}$. Biotites are smaller than $2 \mathrm{~mm}$. The composition was determined by Koch (2006) as follows: K-feldspar (53\%), plagioclase (15\%), quartz $(8 \%)$, amphibole (8\%), biotite (5\%), pyrite $(7 \%)$, and calcite $(4 \%)$. The phenocrysts can constitute about
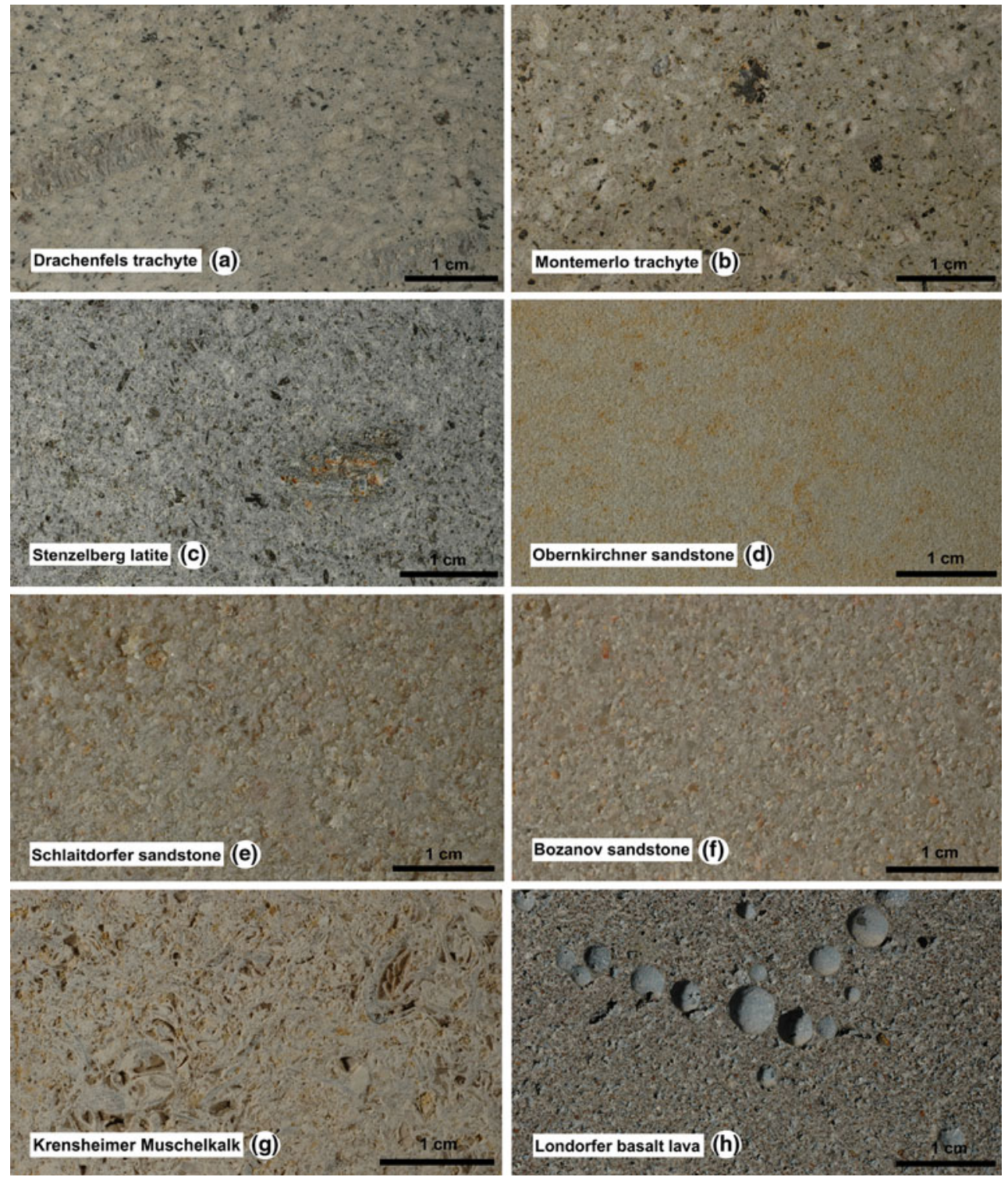

Fig. 6 Cut sections of the investigated stones from Cologne Cathedral (a) Drachenfels trachyte, b Montemerlo trachyte, c Stenzelberg latite, d Obernkirchner sandstone, e Schlaitdorfer sandstone, f Bozanov sandstone, $\mathbf{g}$ Krensheimer Muschelkalk and $\mathbf{h}$ Londorfer basalt lava 
$40 \%$ of the total rock. Accessory minerals are zircon, apatite, and sphene. The groundmass is microcrystalline and mostly consists of anorthoclase, sanidine, plagioclase, and seldom quartz. Plagioclase occurs as euhedral and subhedral, zoned and twinned phenocrysts up to $6 \mathrm{~mm}$ in size as well as in the groundmass. Alkali-feldspars are predominantly anorthoclase and seldom occur as sanidine.

The Stenzelberg latite is a medium gray, porphyritic, and in part porous latite (Fig. 6c). The micro- to cryptocrystalline matrix $(77 \%)$ is mainly composed of plagioclase and sanidine. Plagioclase (14\%), hornblende with individual grain sizes up to $10 \mathrm{~cm}(5 \%)$, augite (1\%), and biotite $(1 \%)$ occurs as phenocrysts. Accessory minerals are apatite, sphene, zircon and ore minerals. The mafic minerals are often accumulated in clusters. Feldspar laths define the flow fabric. The Stenzelberg latite has a low porosity (8.5\%), showing mainly intra- and minor inter-particle pores with heterogeneous pore sizes (Grimm 1990).

The Obernkirchen sandstone is a medium-grained, moderately to well-sorted quartz arenite showing a white to orange color (Fig. 6d). The color is derived from iron oxide and hydroxide. The detrital fraction (maximum grain size 300 microns) is composed of monocrystalline quartz (98\%), muscovite, zircon, tourmaline, rutile and opaque minerals. Grains are rounded, spherical, and rod-shaped with an aspect ratio up to four (Morales Demarco et al. 2007). Most of the grain contacts are concave-convex and sutured. The fabric is grain-supported. The matrix (ca. 5\%) is composed of aggregates consisting of authigenic kaolinite showing the characteristic booklet structure. The cement consists of rare silica (probably syntaxial overgrowths) and iron oxide patches. Obernkirchen represents pure quartz sandstone with a small amount of kaolinite (Dienemann and Burre 1929; Grimm 1990).

The Schlaitdorfer sandstone is a whitish to yellowish coarse-grained, well-sorted often parallel, angular and cross-bedded rock (Fig. 6e). The detrital fraction $(65 \%)$ is represented by quartz (72\%), rock fragments $(12 \%)$, feldspar $(2 \%)$ and cement (14\%). The feldspar is often more intensely weathered. The cement consists of coarse-grained dolomite, in parts silica and rarely illite and kaolinite, which show a dispersed distribution. The main accessories $(<1 \%)$ are apatite, zircon, tourmaline and opaque minerals. Variegated marly clay is mostly accumulated in layers and occurs parallel to the bedding. Grain contacts are mainly along the long axes of the grains and they are often narrowly intergrown (Grimm1990).

The Bozanov sandstone is a coarse-grained to mediumgrained arkosic sandstone (Fig. 6f). It is only weakly cemented and shows a light gray to yellow color. Sporadically clay cement participates in grain cementation as a clay mineral seam or as a crack and gusset pore infilling (smectite). Many grains display an initial interlocking grain boundary with concave-convex grain contacts. The mineralogical composition is given by quartz (79\%), rock fragments (10\%), feldspar (5\%), clay minerals (smectite, kaolinite, around 5\%) and accessories like biotite, zircon and opaque minerals. Very typical are cross-bedding, gradations and shell-shaped cavities and impressions. The feldspar content and its decoration by hematite crystals are very characteristic features. The rock is poorly sorted (Koch 2000; 2001; Přikryl et al. 2010).

The Krensheimer Muschelkalk is a light, brownishgrayish fine porous limestone consisting of shell fragments (Fig. 6g). It is classified as a grainstone according to Dunham (1962) or as a densely packed bio(micro)sparite after Folk (1962). Mussel- and brachiopod shells of 5-7 $\mathrm{mm}$ in size are densely packed in a fine calcite matrix; pores are partially filled with calcite or often filled with residual material. The components are oriented parallel to the bedding, showing a moderate sorting. The composition consists of $75 \%$ biogenic components mainly with micritic rendering, $5 \%$ cement and $20 \%$ pores. The cement is sparitic and partially micro-sparitic. Gusset pores characterize the pore space, particle solution pores, and mould pores. The fabric is grain-supported with mainly long and point contacts (Grimm 1990; Siegesmund et al. 2010).

The Londorfer basalt lava is a brownish to bluish gray basalt (Fig. 6h). Orange-brownish olivine crystals of 1-2 $\mathrm{mm}$ give the rock a weakly porphyritic appearance. The fabric is fine-grained to medium-grained and around the vesicles hyaloophitic. The rock is composed of plagioclase $(50 \%)$, clinopyroxene $(25 \%)$, olivine $(15 \%)$ and ore minerals (ilmenite and magnetite around 10\%). Accessories of a cryptocrystalline nature $(<1 \%)$ and partially glass (up to 50\%) also occur. The rock is highly porous. Besides generally smaller pores, a less frequent pore type of up to $6 \mathrm{~mm}$ in diameter is characteristic. The pores are often coated by light gray-bluish secondary zeolites. Inclusions of quartzite and claystone fragments up to $5 \mathrm{~cm}$ can be observed (Grimm 1990; Steindlberger 2003).

\section{Petrophysical properties}

Analyses were carried out to determine density, porosity and pore size distribution (PSD) on non-deteriorated samples from eight of the natural building stones used at the Cologne Cathedral. Density was measured by buoyancy weighing on cubic samples $(65 \mathrm{~mm})$. The dry mass, the water saturation and the mass of the samples immersed in water were measured to obtain information concerning the porosity (DIN 52102 1988). Furthermore, the pore size distribution was determined by using mercury intrusion porosimetry (MIP) on cylindrical samples (Ø $12.5 \mathrm{~mm}$ ) (van Brakel et al. 1981; Siegesmund and Dürrast 2011). 
Table 2 Bulk and matrix density, porosity, mean and mode pore radius, capillary water uptake, saturation coefficient, vapor diffusion resistance, and sorption

\begin{tabular}{|c|c|c|c|c|c|c|c|c|c|c|}
\hline \multirow[t]{2}{*}{ Rock type } & \multirow[t]{2}{*}{$\begin{array}{l}\text { Bulk } \\
\text { density } \\
\left(\mathrm{g} \mathrm{cm}^{-3}\right)\end{array}$} & \multirow[t]{2}{*}{$\begin{array}{l}\text { Matrix } \\
\text { density } \\
\left(\mathrm{g} \mathrm{cm}^{-3}\right)\end{array}$} & \multirow[t]{2}{*}{$\begin{array}{l}\text { Effective } \\
\text { porosity } \\
\text { (vol.\%) }\end{array}$} & \multirow[t]{2}{*}{$\begin{array}{l}\text { Mean pore } \\
\text { radius } \\
(\mu \mathrm{m})\end{array}$} & \multirow[t]{2}{*}{$\begin{array}{l}\text { Mode pore } \\
\text { radius } \\
(\mu \mathrm{m})\end{array}$} & \multirow[t]{2}{*}{$\begin{array}{l}\text { Capillary } \\
\text { water uptake } \\
(w \text { value }) \\
\left(\mathrm{kg} / \mathrm{m}^{2} \cdot \sqrt{\mathrm{h}}\right)\end{array}$} & \multirow[t]{2}{*}{$\begin{array}{l}\text { Saturation } \\
\text { degree } \\
(s \text { value })\end{array}$} & \multicolumn{2}{|c|}{$\begin{array}{l}\text { Vapor } \\
\text { diffusion } \\
\text { resistance } \\
\text { factor }(\mu)\end{array}$} & \multirow[t]{2}{*}{$\begin{array}{l}\text { Sorption } \\
\text { (max. } \\
\text { moisture } \\
\text { content) } \\
\text { (wt } \%)\end{array}$} \\
\hline & & & & & & & & $z$ & $x$ & \\
\hline Drachenfels trachyte & 2.33 & 2.64 & 11.92 & 0.414 & 1.334 & 0.55 & 0.74 & 37.38 & 17.91 & 1.88 \\
\hline Montemerlo trachyte & 2.35 & 2.66 & 11.76 & 0.108 & 0.211 & 0.99 & 0.71 & 40.49 & 31.82 & 1.11 \\
\hline Stenzelberg latite & 2.46 & 2.69 & 8.53 & 0.017 & 0.013 & 0.30 & 0.76 & 56.39 & 50.20 & 2.78 \\
\hline Obernkirchner sandstone & 2.16 & 2.65 & 18.58 & 0.821 & 3.350 & 1.26 & 0.64 & 15.89 & 14.95 & 0.72 \\
\hline Schlaitdorfer sandstone & 2.10 & 2.63 & 19.91 & 2.891 & 33.497 & 6.68 & 0.64 & 20.56 & 16.93 & 0.38 \\
\hline Bozanov sandstone & 2.17 & 2.63 & 17.79 & 5.953 & 21.135 & 6.90 & 0.65 & 16.51 & 19.69 & 0.75 \\
\hline Krensheimer Muschelkalk & 2.25 & 2.68 & 16.03 & - & $0.64 / 8.2 *$ & 1.30 & 0.59 & 69.45 & 51.25 & 0.29 \\
\hline Londorfer basalt lava & 2.52 & 2.92 & 13.13 & - & $0.0082 / 28 *$ & 0.39 & 0.59 & 37.78 & 38.60 & 1.62 \\
\hline
\end{tabular}

*Bimodal PSD

The investigated stones show medium porosities from $11.8 \%$ (Montemerlo trachyte) to $19.9 \%$ (Schlaitdorfer sandstone), except the Stenzelberg latite, which belongs to low porosity stones with a porosity of $8.5 \%$ (Table 2 ).

The stones investigated in this study have densities from 2.10 to $2.52 \mathrm{~g} / \mathrm{cm}^{3}$ and can be grouped according to the density. The three sandstones have lower densities. Krensheimer Muschelkalk and the trachytes have slightly higher densities. The highest density shows the basalt lava $\left(2.52 \mathrm{~g} / \mathrm{cm}^{3}\right)$ (Table 2).

According to Rüdrich and Siegesmund (2006), the pore size distributions (PSD) of the investigated stones (with the exception of Krensheimer Muschelkalk and Londorfer basalt lava) show a unimodal distribution. The Schlaitdorfer and Bozanov sandstones have a broader distribution of pores ranging $0.0064-82 \mu \mathrm{m}$ with a clear peak of pores at $>10 \mu \mathrm{m}$ (Fig. 7e, f). The Obernkirchner sandstone has a narrower distribution $(0.0064-64 \mu \mathrm{m})$ (Fig. 7d), and the Drachenfels trachyte has even closer $(0.0082-28 \mu \mathrm{m})$ (Fig. 7a). Even strongly limited is the PSD of the Montemerlo trachyte from 0.0064 to $1 \mu \mathrm{m}$ (Fig. $7 \mathrm{~b}$ ), and the Stenzelberg latite with a PSD from 0.0064 to $0.28 \mu \mathrm{m}$ (Fig. 7c) with a relatively narrowed pore radii maximum. Krensheimer Muschelkalk and Londorfer basalt lava show a bimodal PSD (Fig. 7g, h).

Figure 8 shows the correlation of mean pore radius and porosity. In general, it can be remarked that with a higher porosity, the mean pore radius is also high. An exception is the Obernkirchner sandstone, which has a high porosity of $18.6 \%$ and a relatively small mean pore radius of $0.82 \mu \mathrm{m}$.
Moisture properties

Capillary water absorption was measured according to the standard DIN EN 1925 (1995), on cubic samples (65 mm). The measurements were taken in two directions, parallel and perpendicular, to the bedding of the stone. The w-value is the amount of water taken up per area by the stone with the square root of time (Wesche 1996).

The Drachenfels trachyte, Stenzelberg latite, and the Londorfer basalt lava show low capillary water absorption values $\left(w<0.5 \mathrm{~kg} / \mathrm{m}^{2} \sqrt{ } \mathrm{h}\right)$. The Montemerlo trachyte, the Obernkirchner sandstone, and Krensheimer Muschelkalk have a medium value $\left(1-1.5 \mathrm{~kg} / \mathrm{m}^{2} \sqrt{ } \mathrm{h}\right)$; Schlaitdorfer and Bozanov sandstones show a high capillary water absorption value $\left(6.5-7 \mathrm{~kg} / \mathrm{m}^{2} \sqrt{ } \mathrm{h}\right)$ (Snethlage 2005; Siegesmund and Dürrast 2011). The values are listed in Table 2.

The Drachenfels and the Montemerlo trachytes show a mode pore radius [the pore radius corresponding to the region of the steepest slope (Aligizaki 2006)] in the range 0.1-1 $\mu \mathrm{m}$ (Fig. 7a, b; Table 2), which is the lower range of capillary active pores according to Klopfer (1985). These two rocks absorb water slowly with a low to medium $w$ value. The mode pore radius class of the Obernkirchner sandstone ranges from 1 to $6.4 \mu \mathrm{m}$, which is within the medium range of capillary active pore size (Fig. 7d; Table 2). This sandstone shows slow but continuous water suction with a medium $w$ value. The Schlaitdorfer and Bozanov sandstones show mode pore sizes in the range 10-100 $\mu \mathrm{m}$ (Fig. 7e, f; Table 2). These two rocks soak water rapidly and have a high $w$ value. Krensheimer Muschelkalk has a bimodal distribution and two peaks at 
Fig. 7 Pore size distribution of the investigated natural building stones $(\Phi=$ porosity $)$ determined by means of mercury porosimetry. The red bar indicates the percentage of micropores and capillary pores

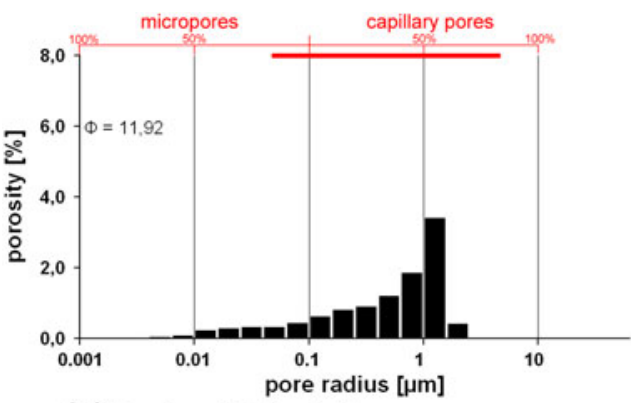

(a) Drachenfels trachyte

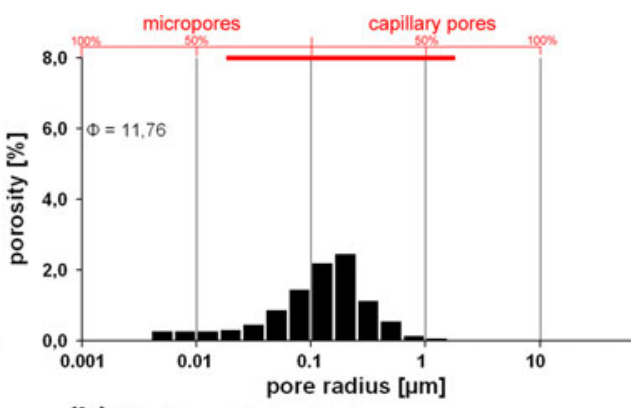

(b) Montemerlo trachyte

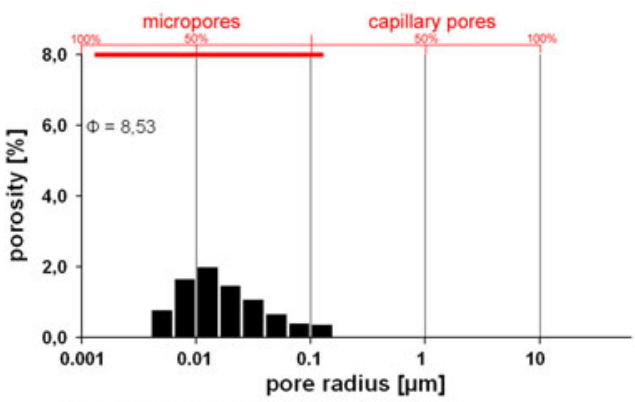

(c) Stenzelberg latite

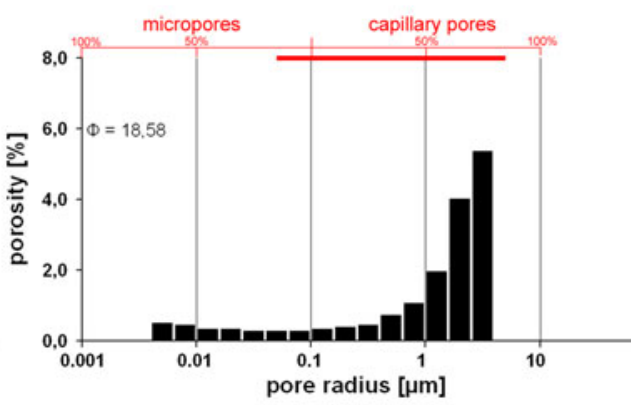

(d) Obernkirchner sandstone

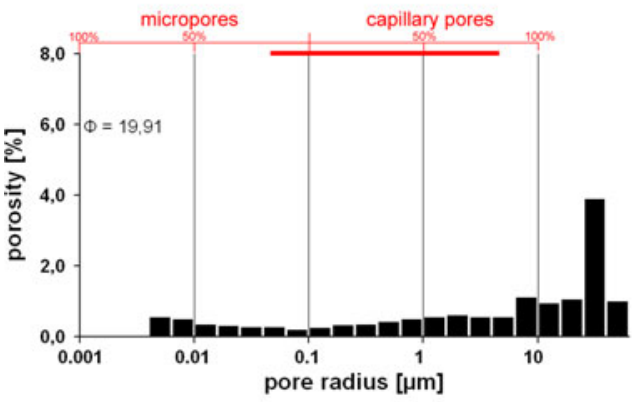

(e) Schlaitdorfer sandstone

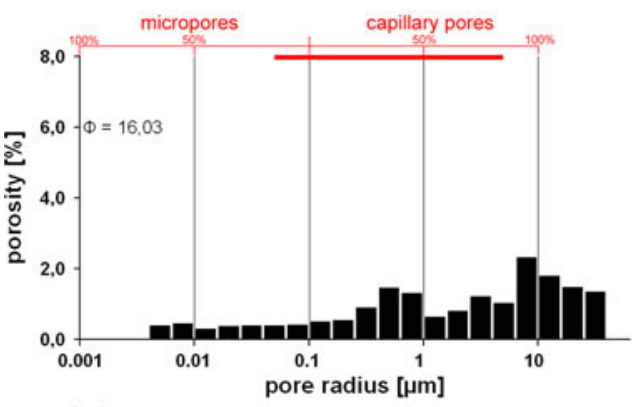

(g) Krensheimer Muschelkalk

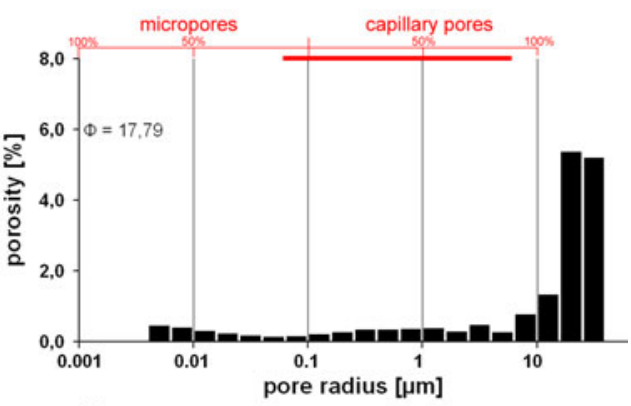

(f) Bozanov sandstone

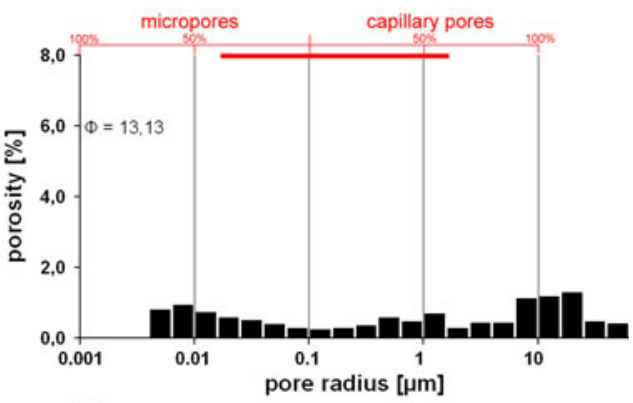

(h) Londorfer basalt lava
0.64 and $8.2 \mu \mathrm{m}$ (Fig. 7g; Table 2). Although $84 \%$ of the porosity belongs to the capillary active pores, the $w$ value is not high, because of the low connectivity of the pore space (Kraus 1985a). The Stenzelberg latite and the Londorfer basalt lava show extremely slow water suction with low $w$ values. Ninety-five percent of the pores in the latite are micropores $(<0.1 \mu \mathrm{m})$ (Fig. 7c). Londorfer basalt lava consists of about $34 \%$ micropores (Fig. 7h).
Based on the measured data, the stones can be divided into three groups (Snethlage 2005): (1) Stenzelberg latite, Londorfer basalt lava, and Drachenfels trachyte have low mean pore radii and low capillary water absorptions ( $w$ values); (2) Montemerlo trachyte, Krensheimer Muschelkalk, and Obernkirchner sandstone have mean pore radii in the lower to medium range of capillary active pore sizes and medium capillary water absorptions; 
mean pore radius - porosity

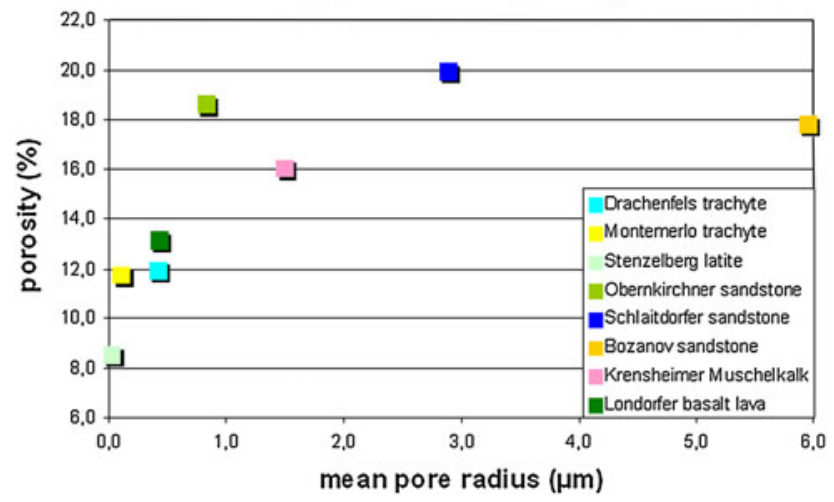

Fig. 8 The investigated natural building stones show a tendency of higher porosity correlated to a higher mean pore radius

(3) Schlaitdorfer and Bozanov sandstones with high mean pore radii have high water absorbing coefficients ( $w$ values).

\section{Water saturation coefficient}

The values for water uptake under vacuum and atmospheric pressure were also determined as well as the degree of saturation ( $s=W_{\mathrm{atm}} / W_{\text {vac }}$ ). Porosity is equivalent to the water uptake under vacuum in percentage of volume relative to the total volume of the rock. The saturation coefficient ( $s$ value) was measured according to the standard, DIN 52103 (1987). It represents the rate of the pore space, which fills up with water under normal atmospheric pressure conditions. The closer the water saturation coefficient comes to 1 , the higher the proportion of pore spaces filled with water under atmospheric pressure. The values for the water saturation of the investigated stones range from 0.59 to 0.76 (Table 2). The Krensheimer Muschelkalk and the Londorfer basalt lava show the lowest $s$ values. The
Schlaitdorfer, Obernkirchner, and Bozanov sandstones are in a medium range. The Drachenfels and Montemerlo trachytes as well as the Stenzelberg latite are rocks with higher $s$ values.

\section{Sorption/desorption}

For measuring the hygroscopic water adsorption, the equilibrated sample weight was measured with ascending and descending relative humidity in steps of $10 \%$ from 15 to $95 \%$, and from 95 to $15 \%$, at $30^{\circ} \mathrm{C}$ on cylindrical samples (Ø 20,50 $\mathrm{mm}$ in length) according to the standard, DIN 66138 (2008). At the hygroscopic level, the water adsorption of a rock is regulated by the humidity of the air, and it is separated into sorption (moisture adsorption) and desorption (moisture release). In the hygroscopic range of 0-95\% relative humidity, moisture content of the rocks increases with rising humidity along so-called sorption isotherms.

The highest mass increase (at 95\% RH) is shown by the Stenzelberg latite with a value of $2.78 \mathrm{wt} \%$, whereas the lowest value was determined for the Krensheimer Muschelkalk (0.29 wt\%) (Table 2; Fig. 9a). The Drachenfels trachyte and the Londorfer basalt lava also show a relatively high water adsorption, whereas the Montemerlo trachyte, the Obernkirchner and Bozanov sandstones, have a medium water adsorption. The Schlaitdorfer sandstone only shows a small mass increase. The Stenzelberg latite, Londorfer basalt lava, and Drachenfels trachyte show a hysteresis in their sorptiondesorption behavior: the decrease of mass is less than the increase, indicating that the stone material dries slower with descending relative humidity and still contains a residue of moisture as a possible indication of capillary condensation (Fig. 9b). The Stenzelberg latite probably

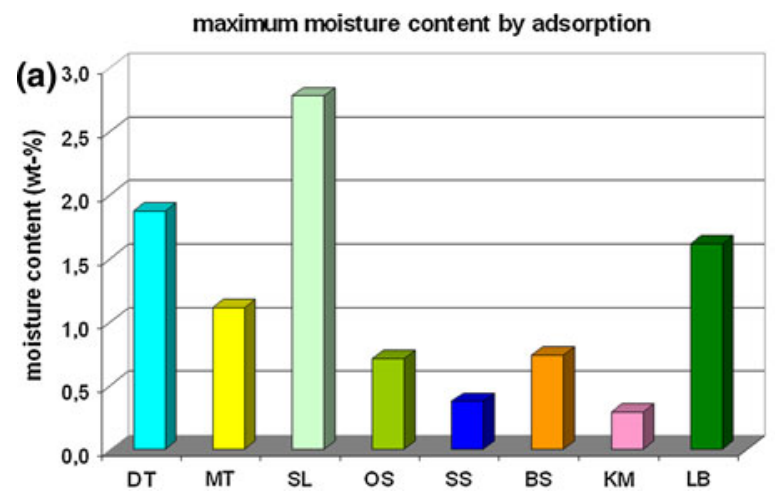

Fig. 9 a The diagram shows the moisture content of the stones by moisture adsorption (sorption) at $95 \%$ relative humidity. b Equilibrium moisture sorption isotherms, showing a significant increase at relative humidity levels $>85 \%$ reflecting capillary condensation.

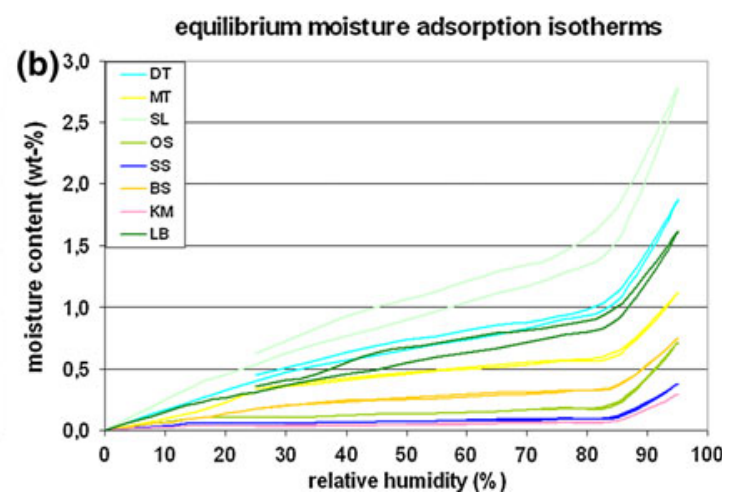

Drachenfels trachyte (DT), Montemerlo trachyte (MT), Stenzelberg latite (SL), Obernkirchner sandstone (OS), Schlaitdorfer sandstone (SS), Bozanov sandstone (BS), Krensheimer Muschelkalk (KM) and Londorfer basalt lava 
shows the effect of capillary condensation, whereas the Montemerlo trachyte and Londorfer basalt lava may possibly show little effect as well.

\section{Water vapor diffusion resistance}

The water vapor diffusion resistance is defined by the vapor diffusion resistance coefficient ( $\mu$ value). It was measured at $20^{\circ} \mathrm{C}$ by using the wet-cup method on diskshaped stone samples ( $\varnothing 50,10 \mathrm{~mm}$ in thickness) according to standard DIN EN ISO 12572 (2001). The water vapor diffusion resistance value indicates to what extent the transport resistance of the water vapor is higher in rock than in air. With the help of the wet-cup method, the $\mu$ value is determined at 50 and $95 \%$ relative humidity $(\mathrm{RH})$. This range represents the central European climate. Of the investigated stones, the Krensheimer Muschelkalk and Stenzelberg latite have a high resistance to water vapor diffusion. Drachenfels and Montemerlo trachyte as well as the basalt lava show a medium resistance, respectively. The sandstones have the highest permeability of the investigated stones (Table 2; Fig. 10a). The Drachenfels trachyte shows a remarkable directional dependence of water vapor diffusion resistance which could mainly be controlled by the flow fabric (Table 2). A higher resistance correlates with a higher amount of micropores (Fig. 10b): capillary condensation takes place in micropores, which holds back water due to solvent water diffusion. This leads to capillary suction (retention), which is much slower than water vapor diffusion (Snethlage 1984). Only the Krensheimer Muschelkalk does not fit this correlation.

\section{Moisture expansion-hydric dilatation and hygric dilatation}

The length and volume increase and decrease of rocks with changes of moisture is well known as hygric (in the range between 0 and 95\% RH) and hydric (water saturated) expansion and contraction (Delgado Rodrigues and Charola 1996; Weiss et al. 2004; Ruedrich et al. 2010a). Hydric dilatation is measured on cylindrical stone samples $(\varnothing 20$, $50 \mathrm{~mm}$ in length) completely immersed in water. An overview of the hydric dilatation on the different stone materials is given in Table 3. In general, hydric dilatation is low. The highest dilatation is determined at the

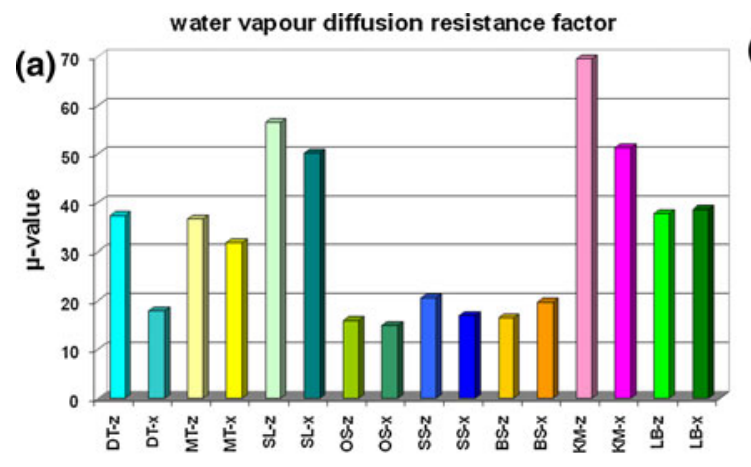

Fig. 10 a Water vapor diffusion resistance factor ( $\mu$ value) of the investigated stones, perpendicular $(z)$ and parallel $(x)$ to the bedding of the stones; $\mathbf{b}$ average water vapor diffusion resistance factor in correlation with the percentage of micropores of the investigated stones. The diagrams indicate the diversity of the stone properties and (b)

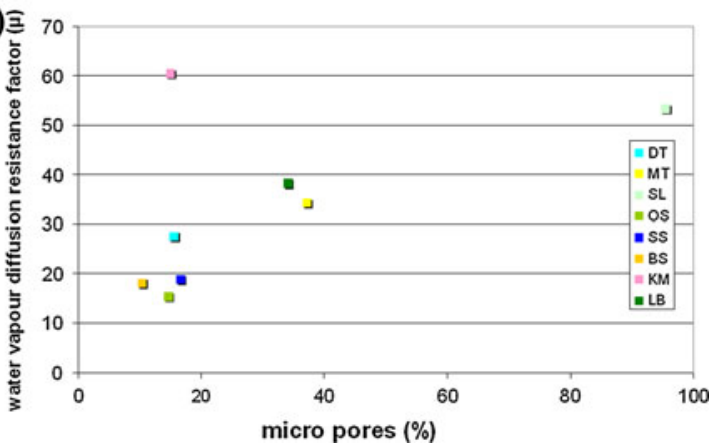

show a correlation of higher water vapor diffusion resistance due to a higher amount of micropores. Drachenfels trachyte (DT), Montemerlo trachyte (MT), Stenzelberg latite (SL), Obernkirchner sandstone (OS), Schlaitdorfer sandstone (SS), Bozanov sandstone (BS), Krensheimer Muschelkalk (KM) and Londorfer basalt lava
Table 3 Thermal expansion coefficient and hygric dilatation

\begin{tabular}{lcccccc}
\hline Rock type & \multicolumn{2}{c}{ Thermal dilatation coefficient (expansion) } & & \multicolumn{2}{l}{ Hydric dilatation } \\
\cline { 2 - 3 } & $x\left(10^{-6} \mathrm{~K}^{-1}\right)$ & $z\left(10^{-6} \mathrm{~K}^{-1}\right)$ & Anisotropy $(\%)$ & & $x(\mathrm{~mm} / \mathrm{m})$ & $z(\mathrm{~mm} / \mathrm{m})$ \\
\hline Drachenfels trachyte & 5.32 & 6.05 & 12.0 & 0.253 & 0.236 \\
Montemerlo trachyte & 6.25 & 4.65 & 25.5 & 0.291 & 0.316 \\
Stenzelberg latite & 9.41 & 7.36 & 21.7 & & 0.196 & 0.230 \\
Obernkirchner sandstone & 11.60 & 12.17 & 4.6 & & 0.089 & 0.060 \\
Schlaitdorfer sandstone & 9.65 & 11.96 & 19.3 & & 0.025 & 0.025 \\
Bozanov sandstone & 8.78 & 8.65 & 1.5 & 0.027 & 0.013 \\
Krensheimer Muschelkalk & 4.75 & 6.82 & 30.3 & & 0.000 & 0.005 \\
Londorfer basalt lava & 5.32 & 5.78 & 8.0 & & 0.226 & 0.186 \\
\hline
\end{tabular}


Montemerlo trachyte with a value of $0.316 \mathrm{~mm} / \mathrm{m}$ perpendicular to the bedding. High hydric swelling was measured in the Drachenfels trachyte, Stenzelberg latite, and Londorfer basalt lava. The Obernkirchner sandstone has medium hydric swelling, whereas the other two sandstones, Schlaitdorfer and Bozanov, have low hydric dilatation. The length change of the Krensheimer Muschelkalk is within the accuracy of measuring (Table 3).

Generally, hydric dilatation is anisotropic in nature, and values for anisotropy of about $50 \%$ are reported in the literature (Rüdrich et al. 2005). With respect to the rocks from the Cologne Cathedral, only the Bozanov and Obernkirchner sandstones show a medium anisotropy. Furthermore, the expansion of the different stones is timedependent: Londorfer basalt lava, Drachenfels trachyte, Bozanov and Schlaitdorfer sandstones, have already reached over $50 \%$ of their maximum expansion perpendicular to the bedding in the first $30 \mathrm{~min}$. Montemerlo trachyte attained $88 \%$ of the total expansion in that time. Obernkirchner sandstone already expanded to its whole extent after $5 \mathrm{~min}$. Stenzelberg latite has only reached 13\% in the first $30 \mathrm{~min}$. This time dependence is ascribed to different pore space properties. Where stones with wellinterconnected pores and relatively high porosities show a fast expansion, stones with a less well-interconnected pore space have a slower expansion (Rüdrich et al. 2005).

Hygric dilatation processes occur with changes of the relative humidity. The measured hygric expansion differs from hydric expansion. The sandstones show low hygric dilatation values, Schlaitdorfer $(0.063 \mathrm{~mm} / \mathrm{m})$ and Bozanov $(0.010 \mathrm{~mm} / \mathrm{m})$. Moisture expansion in the Krensheimer Muschelkalk is negligible $(0.001 \mathrm{~mm} / \mathrm{m})$. Obernkirchner sandstone has a somewhat higher expansion result $(0.065 \mathrm{~mm} / \mathrm{m})$. Stenzelberg latite shows high hygric expansion with dilatation in the $z$ direction (perpendicular to bedding) of $0.231 \mathrm{~mm} / \mathrm{m}$. The Londorfer basalt lava also has a high hygric expansion $(0.185 \mathrm{~mm} / \mathrm{m})$. Hygric dilatation in the Montemerlo trachyte $(0.142 \mathrm{~mm} / \mathrm{m})$ is slightly higher than that of the Drachenfels trachyte $(0.110 \mathrm{~mm} / \mathrm{m})$. With increasing relative humidity, a sharper increase of hygric expansion can be observed at around $80-85 \%$ relative humidity (Fig. 11).

\section{Thermal dilatation}

Thermal expansion was measured on cylindrical samples (Ø $15,50 \mathrm{~mm}$ in length) within five consecutive heating cycles from 20 to $95^{\circ} \mathrm{C}$. The length variation (resolution $<1 \mu \mathrm{m}$ ) was determined as a function of temperature and was measured in two directions: perpendicular ( $z$ direction) and parallel ( $x$ direction) to the bedding. The thermal expansion coefficient was calculated $(\alpha=\Delta l / l \times \Delta T)$ as well as the residual strain $\left(\varepsilon_{\mathrm{rs}}=\Delta l_{\mathrm{rt}} / l\right)$ after one heating

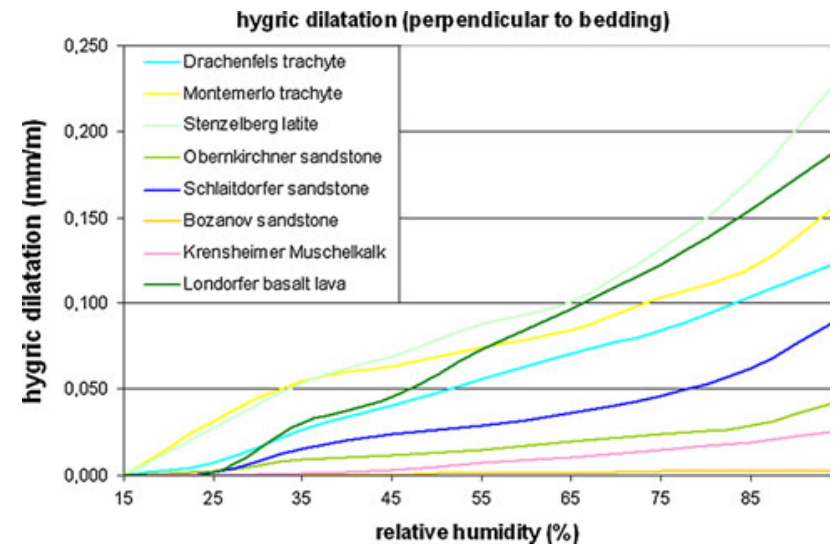

Fig. 11 Hygric dilatation perpendicular to the bedding of the stones with relative humidity ranging $15-95 \%$

cycle (Zeisig et al. 2002; Koch and Siegesmund 2001). Anisotropy was determined by the difference of the expansion coefficients in both directions.

Drachenfels trachyte and Londorfer basalt lava show low thermal expansion coefficients and only little anisotropy. Montemerlo trachyte and Krensheimer Muschelkalk display low expansion values and pronounced anisotropy. Bozanov sandstone has a medium coefficient but no anisotropy. Stenzelberg latite has a medium thermal expansion coefficient and anisotropy of about $21 \%$. Obernkirchner and Schlaitdorfer sandstones show high thermal expansion coefficients, only the latter displays an anisotropy of about 19\% (Table 3). No residual strain was observed for the investigated stones.

\section{Strength properties}

The uniaxial compressive strength was measured in two directions ( $z$ direction: perpendicular and $x$ direction: parallel to the bedding of the rock) on planar cylindrical samples ( $\varnothing 50,50 \mathrm{~mm}$ in length; $r / d=1)$ according to the standard DIN EN 1926 (1999). Based on the scale 3 effect, the compressive strength ratio may differ up to $20 \%$ higher by measuring samples with $r / d$-ratio of 1 instead of $r / d$ ratio of 2 (Peschel 1983). The load was applied with a strain rate of $1,000 \mathrm{~N} / \mathrm{s}$ until failure. The compressive strength varies between 45.1 and $126.4 \mathrm{~N} / \mathrm{mm}^{2}$ (Table 4). The Stenzelberg latite has the highest compressive strength $\left(126.4 \mathrm{~N} / \mathrm{mm}^{2}\right)$, while the strength values for the Krensheimer Muschelkalk, Schlaitdorfer, and Bozanov sandstones are less than $50 \mathrm{~N} / \mathrm{mm}^{2}$. Only the Stenzelberg latite belongs to the high strength rocks, while rocks with compressive strength values between 55 and $70 \mathrm{~N} / \mathrm{mm}^{2}$ belong to the low strength rocks (e.g., Drachenfels trachyte and Londorfer basalt lava) (Mosch 2008). Obernkirchner sandstone and Montemerlo trachyte display higher uniaxial compressive strength values. Except for the Obernkirchner 
Table 4 Uniaxial compressive strength, tensile strength and flexural strength of the investigated rocks in non-weathered condition

\begin{tabular}{|c|c|c|c|c|c|c|}
\hline \multirow[t]{2}{*}{ Rock type } & \multicolumn{2}{|c|}{ Uniaxial compressive strength $\left(\mathrm{N} / \mathrm{mm}^{2}\right)$} & \multicolumn{2}{|c|}{ Tensile strength $\left(\mathrm{N} / \mathrm{mm}^{2}\right)$} & \multicolumn{2}{|c|}{ Flexural strength $\left(\mathrm{N} / \mathrm{mm}^{2}\right)$} \\
\hline & $z$ & $x$ & $z$ & $x$ & $z$ & $x$ \\
\hline Drachenfels trachyte & 65.54 & 66.59 & 3.087 & 3.674 & 5.999 & 6.100 \\
\hline Montemerlo trachyte & 75.53 & 84.75 & 3.439 & 3.680 & 6.725 & 8.195 \\
\hline Stenzelberg latite & 126.41 & 120.02 & 9.735 & 8.621 & 15.707 & 9.881 \\
\hline Obernkirchner sandstone & 86.72 & 76.29 & 4.594 & 4.669 & 7.992 & 6.825 \\
\hline Schlaitdorfer sandstone & 47.59 & 51.44 & 3.256 & 3.343 & 6.492 & 5.733 \\
\hline Bozanov sandstone & 45.10 & 52.08 & 3.462 & 3.343 & 3.975 & 4.410 \\
\hline Krensheimer Muschelkalk & 48.35 & 52.74 & 4.498 & 4.544 & 8.467 & 6.763 \\
\hline Londorfer basalt lava & 63.10 & 72.18 & 5.099 & 5.921 & 12.567 & 12.749 \\
\hline
\end{tabular}

sandstone and the Montemerlo trachyte, a directional dependence of the compressive strength is less pronounced in the other samples (Table 4).

Flexural strength is an important mechanical property for natural building stones. Failures due to bending stress are more common than those caused by compressive or shear stresses. The flexural strength values are usually lower than the compressive strength values for a rock. Mosch (2008) mentions a correlation of 10:1 for the compressive to the flexural strength. Flexural strength was measured according to the standard DIN EN 12372 (1999) on oblong samples $(150,40,25 \mathrm{~mm})$ in two direction (perpendicular and parallel to the bedding of the rock). The flexural strength values of the investigated rocks cover the range between 4.0 (Bozanov sandstone) and $15.7 \mathrm{~N} / \mathrm{mm}^{2}$ (Stenzelberg latite) (Table 4). Londorfer basalt lava has a high flexural strength, whereas the Schlaitdorfer sandstone, the Drachenfels and Montemerlo trachytes show medium flexural strength values. The Obernkirchner sandstone and the Krensheimer Muschelkalk display somewhat higher flexural strength values. The values are listed in Table 4.

In order to obtain the values of the tensile strength, measurements were made using the Brazil Test according to the standard DIN 22024 (1989). Investigations were performed on disk-shaped specimens ( $\varnothing 40,20 \mathrm{~mm}$ in thickness). The load was applied with a strain rate of $30 \mathrm{~N} / \mathrm{s}$. Measurements were applied in two directions (perpendicular and parallel to the bedding of the rock). The tensile strength varies between 3.1 (Drachenfels trachyte) and $9.7 \mathrm{~N} / \mathrm{mm}^{2}$ (Stenzelberg latite), depending on the sample and direction of load with respect to the rock fabric. Of the investigated stones, Londorfer basalt lava has a medium tensile strength. Obernkirchner, Schlaitdorfer and Bozanov sandstones, Krensheimer Muschelkalk, and Montemerlo trachyte have a lower tensile strength (Table 4). Many rocks show the smallest tensile strength perpendicular to the bedding. In the case of the samples investigated, the heterogeneity may also play an important role in explaining the observed data (Table 4). However, the anisotropy of all the rocks is not very well pronounced.

\section{Discussion}

Building stones of the Cologne Cathedral: deterioration phenomena and decay processes

Due to its building history, many different building stones were implemented at the Cologne Cathedral, which show different deterioration behavior. These stones differ not only in their genesis, but also in their visual appearance, their mineralogical composition as well as in their porosity features and rock fabric, and therefore in their petrophysical properties, which again determine the deterioration behavior. Furthermore, exposition, climatic situation, industrial-based pollution, and building physics play a major role (for further discussions see Siegesmund and Snethlage 2011).

A high porosity in connection with a high water uptake is considered as having a high damage potential. High water uptake values ( $w$ value) combined with a high saturation coefficient ( $s$ value) are the first indicators for a possible susceptibility to weathering, or in other words, pollutant transport, hygric and hydric expansion, frost damage and salt crystallization in the pore spaces, etc. Along with the capillary water uptake, an important role is also played by the sorption (water derived from the absorbed humidity) and desorption (water released in relation to the relative humidity). This determines, among others the drying behavior, which is influenced by the capillary transport, the water vapor diffusion and the critical moisture of the stone.

The capillary absorption capacity of a porous stone is defined by its water uptake coefficient ( $w$ value). This is a process driven by the capillary forces that originate in the 
micropores and capillary pores (Klopfer 1985). Rocks with a high amount of capillary pores are expected to have a high $w$ value, which means they have the capacity to rapidly absorb water by capillary uptake in the pore spaces. Stones with low capillary absorption (suction) have a $w$ value of $<0.5 \mathrm{~kg} / \mathrm{m}^{2} \cdot \sqrt{\mathrm{h}}$, those with medium absorption range from 0.5 to $3.0 \mathrm{~kg} / \mathrm{m}^{2} \cdot \sqrt{\mathrm{h}}$ and stones showing strong water suction have $w$ values $>3.0 \mathrm{~kg} / \mathrm{m}^{2} \sqrt{\mathrm{h}}$ (Snethlage 2005). A $w$ value of $>3.0 \mathrm{~kg} / \mathrm{m}^{2} \cdot \sqrt{\mathrm{h}}$ suggests a sufficient uptake of water in the pore spaces to keep the stone moist for a long time and to mobilize any salts present. The importance of this parameter cannot be underestimated, since a strong absorption capacity simultaneously means that a high pollutant uptake and distribution occurs in the pore spaces. This is the reason why dense building stones will sometimes weather on the surface, whereas those with a good absorption capacity will deteriorate at depth.

The water saturation coefficient ( $s$ value) gives an approximate value for the frost resistance of natural building stones. Hirschwald (1912) proposed the following guideline values using the saturation coefficient: when $s<0.80$ the rock is weathering and frost resistant; for values ranging between 0.80 and 0.90 it is uncertain and further investigations are necessary; and when $s>0.90$ the rock is not frost resistant. Similar limitations are given by the standard DIN 52103: a rock with $s<0.75$ is considered weathering resistant and susceptible to weathering when $s>0.9$. A $s$ value $>0.75$ indicates that if the water supply is high enough, the pore space is filled with water to a higher degree and frost action could happen.

Sorption is the adsorptive addition of water from the air. This occurs under isothermic conditions in two steps: 1. Adsorption of molecular water films on the inner surface of the stone material, and 2. Capillary condensation in pores

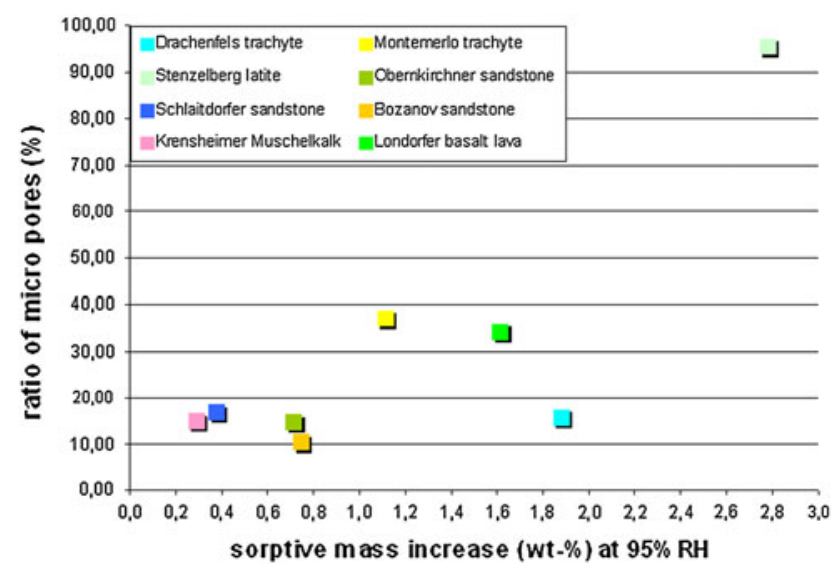

Fig. 12 The investigated stones of the Cologne Cathedral show a tendency towards a higher percentage of micropores correlated to a higher water adsorption due to capillary condensation. However, the ratio of micropores in the Drachenfels trachyte would suggest a lower sorption less than $0.1 \mu \mathrm{m}$ in size (Kraus 1985a). The pore size distribution gives a clue to the sorptive water uptake: with an increasing amount of micropores the sorption increases as well due to capillary condensation, assuming the pore space communicates well (Fig. 12).

Pore size distribution and porosity of a rock are responsible for water and moisture uptakes as well as water transport. Generally, pores are divided due to their size into different classes: micropores $(<0.1 \mu \mathrm{m})$, capillary pores (0.1 $\mu \mathrm{m}-1 \mathrm{~mm})$, and macropores ( $>1 \mathrm{~mm}$ ) (Klopfer 1985). When capillary pores are present, water can be taken up and rises by capillary action. Fluid and capillary transport mechanisms are the main driving factor. On the other hand, micropores adsorptively accumulate water from the air at their inner surface (capillary condensation). Surface and solution diffusion are the main transport mechanisms (Siegesmund and Dürrast 2011).

The drying of natural building stones is a function of the capillary transport, the water vapor diffusion and the critical moisture of the stone. According to Kraus (1985a), when a water-saturated rock dries, the relative rapidly absorbed water from precipitation is by comparison released at a slower rate. This lengthy process is due to the capillary absorbed water being released to a large extent by vapor diffusion. The first stage in the drying of a stone occurs over the rock surface, as an evaporation surface, provided that the capillary water is replenished from the deeper parts of the rock. When this capillary thread tears off (critical moisture), water vapor diffusion transport starts. Thus, a natural stone with a low critical moisture can dry much faster. In this case, the capillary transport forces are much stronger. At a value less than the critical moisture, the significant determining factor for the drying process is the water vapor conductivity. When a stone has a high water vapor diffusion resistance, the water release becomes progressively slower. This can be correlated to the pore size distribution, whereby a high resistance can be expected as a result of a large proportion of micropores. Since the capillary water is condensed and bound, the expulsion of any water from the stone material is very difficult (Snethlage 1984). Furthermore, the communicability of the pore space plays a certain role. The process of drying in this second phase decelerates more and more, because the distances of water vapor diffusion transportation become greater until moisture reaches equilibrium with the surrounding air. Besides water vapor diffusion also surface and solution diffusion takes place (Kraus 1985a). Therefore, the length of the first drying phase is mainly determined by the percentage of capillary active pores, besides external climatic factors, e.g., wind, temperature, and insulation, etc., the second phase is determined by water vapor diffusion properties; considering the general water uptake and saturation properties ( $w$ and 
$s$ values) and the connectivity of the pore space. Furthermore, Kraus (1985a) mentions, that with a capillary active and well communicating pore system, water may even be transported further into deeper zones of the stone, although the active water supply already ended.

Moisture expansion (hydric and hygric dilatation) describes the length or volume change which most natural building stones undergo by wetting in correspondence to climatic factors of the environment. The processes responsible are not yet ultimately defined; the volume change may be attributed to the swelling of clay minerals as well as to disjoining pressure. This latter effect is relevant for all minerals, and significant moisture expansion is correlated to a large amount of micropores $(<0.1 \mu \mathrm{m})$ (Ruedrich et al. 2010a). According to Rüdrich et al. (2005), hygric dilatation is essentially a reversible process, i.e., no residual strain is ascertained after reducing relative humidity back to the starting value. This only applies for demineralized water, which means by the presence of damaging salts in building stones, these processes might be affected remarkably.

A number of deterioration phenomena can be traced back to the volume increase of natural building stones by moisture expansion, e.g., scaling, flaking, and granular disintegration. In most cases, building stones show an irregular moisture distribution, whereby moisture gradients diverge leading to a build-up of strain and resulting decay.

Rocks show volume changes due to moisture content, as well as they undergo length or volume changes due to changes of temperature. This process is determined by the individual properties of the mineral content and composition but also by the structure and the rock fabric of the natural building stone. The volume change does not necessarily increase linearly to the temperature, which means that the linear thermal expansion coefficient is often only valid for a certain temperature interval (Siegesmund and Dürrast 2011). The residual strain is of pronounced relevance in terms of deterioration resistance. A permanent length change of building stones after returning to the initial temperature can be traced to microcracking and thus indicates potential decay (Ruedrich et al. 2010b).

Strength properties such as compressive, flexural, and tensile strengths are rock parameters, which also limit the durability of dimension stones. Material failure occurs, when stresses induced by mechanical weathering processes exceed the strength of the material. In respect to frost and salt deterioration resistance, damage occurs when the stresses due to salt and ice crystallization exceed the tensile strength (Rüdrich et al. 2005). The strength properties correlate to the grain fabric cohesion. Important fabric parameters for the strength are the porosity, the pore size distribution, the grain size, the grain contacts, the type and state of cementation as well as a preferred grain boundary orientation.

Drachenfels trachyte has a medium porosity, a low capillary water uptake and a high $s$ value, which might suggest a certain sensitivity to frost-related weathering. Luckat (1973b) demonstrated that the Drachenfels trachyte is especially sensitive to salt weathering processes. Flaking and scaling can be pronounced, especially in the direct neighborhood of carbonate replacement stones (Kraus 1985a; von Plehwe-Leisen et al. 2007). Flaking and scaling are often noticeable as a predecessor for further accelerated decay by fissures, cracks, crumbling and material loss.

The sorptive water uptake of the building stone is in a medium range, moisture expansion is relatively high, and with $84 \%$ the percentage of capillary active pores is quite high. In terms of desiccation of the Drachenfels trachyte, water vapor diffusion transport mechanisms already start at relatively high water content ( $>3 \mathrm{wt} \%$ ) of the stone (Kraus 1985a). In respect to its water vapor diffusion resistance, a long drying time is observed, showing after 15 days no complete drying (Kraus 1985a). Furthermore, Kraus (1985a) mentioned, that building stones exposed to the natural environment experience a rewetting before they might dry out completely. While uniaxial compressive strength is in the medium range of the investigated stones, tensile and flexural strength are low. For the Drachenfels Trachyte a continuous high water yield, and therefore sufficient water supply as "support" for deterioration mechanisms exists, which presumably are due to the high s-value, sorptive water uptake, vapor diffusion resistance and retarded drying. Here different moisture gradients are assumed, whereby hydric dilatation has an effect to a certain extent. In the context of electrolytes i.e., ions dissolved from other carbonate stones nearby for example, salt deterioration processes might be enhanced in addition to pollution. The low strength values, especially for the tensile strength, indicate a modest resistance against weathering.

Montemerlo trachyte has been used at the Cologne Cathedral since 2005 and still does not exhibit any structural damage. However, Lazzarini et al. (2008) reported on exfoliation and flaking, powdering and alveolic weathering for the Montemerlo trachyte in Venice (Italy) mainly related to salt deterioration. The relatively low water uptake only allows a certain uptake of pollutants but porosity and pore size distribution assume a prolonged drying time. Therefore, crystallization of salts can occur and due to the low tensile strength, damage is possible.

The typical deterioration phenomenon of the Stenzelberg latite is a scaling of $2-3 \mathrm{~mm}$ thick scales (Fig. 5e). Stenzelberg latite may have a low capillary water uptake, but also a high water saturation $(76 \%)$, which indicates a certain liability to frost-related decay. Sorption is slow, but 
shows high values and hysteresis, which implies a decelerated moisture release. The high percentage of micropores underlines the slow moisture uptake and also release. A further retardation and especially zoning of these processes is to be expected due to the technical surface treatment and the material compaction involved. Thereby gradients of moisture, material consistency and strength are evolved, which could lead to surface parallel detached material layers of a few millimeter in thickness due to frost shattering. Hydric dilatation might have a certain but minor impact.

Obernkirchner sandstone is mentioned as a building stone with a high resistance against weathering. It mainly shows superficial deterioration phenomena, which does not have a severe structural impact, except of the gypsum crusts (Fig. 5b). The formation of these crusts indicates a strong pollution emission at the Cologne Cathedral in the past. Due to the application of a coat of paint, to color adjust to the Krensheimer Muschelkalk, applied in the 1930s, surface parallel scaling of approximately 1-2 mm occurs. Spalling along edges near to joints (Fig. 5c) is presumably due to mechanical impact of strain, caused by the joint fill material. However, Morales Demarco et al. (2007) determined a strength loss due to water saturation of about $14 \%$ for the Obernkirchner sandstone.

Schlaitdorfer sandstone shows characteristic deterioration in the form of rounding and notching in context with scaling and granular disintegration to sand (Fig. 5d). Kraus (1985a) describes the decay of Schlaitdorfer sandstone due to loss of cementation through the formation of damaging salts, i.e., gypsum due to high $\mathrm{SO}_{2}$-immision. The Schlaitdorfer sandstone has a high porosity and a high $w$ value, which determines the high water uptake. The formation of gypsum in the pores leads to accumulation of damaging salts and thereby to scaling and back-weathering. Efes (1980) observed an increase of smaller pores near the surface and a reduction of water vapor diffusion up to $50 \%$, leading to retarded moisture release. With a saturation coefficient of 0.64 , the Schlaitdorfer sandstone is not vulnerable to frost attack. On the Schlaitdorfer sandstone, a second desiccation phase by water vapor diffusion starts at a water content of $<2 \mathrm{wt} \%$. During this drying phase by water vapor diffusion, a pronounced accumulation of not readily soluble gypsum salts exists in the pore space (Kraus 1985a).

At present, the Bozanov Sandstone shows little evidence of decay except spalling along the edges caused by the mounting of the building stones. These stones have only been implemented at the Cologne Cathedral since 2001. Přikryl et al. (2010) have reported on granular disintegration, scaling, flaking, crust formation, blistering, fracturing, salt efflorescence, alveoli formation for the mediumgrained Bozanov sandstone. They detected a high amount of water soluble salts responsible for blistering, granular disintegration, scaling and flaking. Other weathering processes described are: cyclical wetting and drying, freezethaw cycles, a different thermal expansion of insulated stone surfaces and less heated interior areas of the stone. The petrophysical data of the present investigations support these observations. Although Bozanov sandstone does not have a very high water saturation degree, the capillary water uptake is high. Thus, water supply is high, promoting frost-related weathering as well as possible high loads of damaging salts leading to salt deterioration phenomena. Since strength values are low, these decay processes may propagate to a vast extent. The thermal dilatation coefficient supports the assumption of structural deterioration due to different temperature gradients.

Krensheimer Muschelkalk and Londorfer basalt lava are building stones with a high resistance against weathering. The main deterioration phenomenon of the Krensheimer Muschelkalk at the Cologne Cathedral is black surface crusts, which occur solely in rain-protected areas (Fig. 5f). Due to the decrease of $\mathrm{SO}_{2}$-emission over the last several years, this decay probably will regress as well (Siegesmund et al. 2007; Török et al. 2010). The accumulated pollution of the past certainly affects historical monuments in the present but also in the future. Krensheimer Muschelkalk shows microkarst phenomena, which are typical for carbonate stones and less problematic.

Londorfer basalt lava is only affected by pronounced microbiological growth, which is associated with a great number of large pores (Grimm 1990).

\section{Requirements for replacement stones}

At the Cologne Cathedral exists a material mix of sandstones and carbonates as well as volcanic rocks. This mixed diversity of material on one building is an exception and a great challenge. Owing to the long building history and the continuous repair works, Drachenfels trachyte is found in masonry bonds together with Stenzelberg latite, Obernkirchner sandstone, Krensheimer Muschelkalk and Londorfer basalt lava. Due to actual restoration works, Montemerlo trachyte is integrated into the masonry bond. Occasionally the Schlaitdorfer sandstone is also found together with the medieval Drachenfels trachyte. This indicates, that a potential replacement stone for Drachenfels trachyte has to be compatible with all other stone materials, i.e., its basic properties have to be suitable with all the other stone materials. In addition to it, Bozanov sandstone is used as a replacement material for the Schlaitdorfer sandstone.

To assess the compatibility of weathered and fresh stones, Snethlage (2005) suggests that the properties of a replacement stone should be in a similar range as the 
original stone. The mineralogical composition and the optical appearance are important criteria for replacement stones. Furthermore, the porosity, the pore size distribution, the capillary and sorptive water uptake, the degree of saturation, the water vapor diffusion value and the strengths as well as the Young's modulus of elasticity (E-modulus) are necessary to determine. Many of the parameters required, according to Snethlage (2005) were determined in the present study.

\section{Mineralogy}

In terms of the mineralogical phase composition, the implemented stones at the Cologne Cathedral cover a wide range. Since the different building stones (sandstones, carbonates, and volcanic rocks) exist together in the masonry bonds, it is not possible to find the particular replacement material of the same mineralogical classification. Therefore it is of crucial importance, that the petrophysical data, especially porosity and moisture behavior are compatible.

\section{Optical properties}

In general, all building stones of the Cologne Cathedral show gray to black surfaces when weathered or are originally grayish-black, except for the Krensheimer Muschelkalk in rain-washed areas. Quarry-fresh stones show varying optical appearances. Stenzelberg latite and Londorfer basalt lava are both dark gray stones. Drachenfels trachyte and Krensheimer Muschelkalk are originally light grayish to beige stones. While the weathered Drachenfels trachyte at the Cologne Cathedral shows black surface crusts, the carbonate rock also forms black gypsum crusts in rain-protected wet areas. However, where the stone is washed, the light beige-gray color may even bleach somewhat. Schlaitdorfer and Obernkirchner sandstones originally show a similar light beige to yellow and orange color, but weather differently. While the Obernkirchner sandstone develops a grayish-black surface layer, the Schlaitdorfer sandstone forms dark brown gypsum crusts, but also tends to show some greenish microbiological growth. Besides the color matching, also structural features i.e., grain sizes are critical for the optical properties. The employed sandstones have different appearances in respect to their grain sizes. The Obernkirchner sandstone is a finegrained sandstone, while Schlaitdorfer sandstone is coarsegrained. The actual replacement stone for the Schlaitdorfer sandstone is the coarse-grained sandstone from Bozanov. For the recently employed Bozanov sandstone, weathering proceeds slower and only minor formation of dark crusts can be anticipated, since the period of high pollution impact has changed since the 1970s and 1980s. Moreover, the Bozanov is free of carbonate minerals, and is therefore less sensitive to the formation of gypsum crusts.

The actual replacement material for Drachenfels trachyte, the Italian trachyte from Montemerlo has a similar trachytic matrix, but is slightly more brownish in color intensity. From an aesthetical point of view, the stone is visually compatible with the slightly weathered Drachenfels trachyte. However, in areas where the medieval building stone is weathered and shows intense black crusts, the newly inserted Italian trachyte stands out quite significantly. Even stronger is the difference of weathered Schlaitdorfer to Bozanov sandstone. To cope with the situation of these different appearances, the Obernkirchner sandstone and Drachenfels trachyte were painted to color adjust to the light gray Krensheimer Muschelkalk in the beginning of the twentieth century (Schumacher 2004). The actual discussion on matching optical properties is whether to apply an "aqua sporka" stain onto the new stones or to employ laser cleaning to the old weathered stones.

\section{Petrophysical criteria}

In terms of porosity, all investigated stones except the Stenzelberg latite belong to a medium porosity class (Snethlage 2005, Siegesmund and Dürrast 2011). Moreover, both the trachytes and Londorfer basalt lava are in the lower range of medium porosity (see also Stück et al. 2008).

In view of the pore size classes, clear distinctions are registered. Figure 7 shows that the stones from the Cologne Cathedral diverge in terms of their pore size distribution. The Drachenfels trachyte, Schlaitdorfer, Obernkirchner and Bozanov sandstones, as well as the Krensheimer $\mathrm{Mu}$ schelkalk have $83.3-89.6 \%$ capillary active pores. Londorfer basalt lava and Montemerlo trachyte show 65.8 and $62.8 \%$ capillary pores. Stenzelberg latite is the other extreme with $95.4 \%$ micropores and only $4.6 \%$ capillary pores. Due to its high percentage of micropores, Stenzelberg latite probably shows the effect of capillary condensation. Montemerlo trachyte and Londorfer basalt lava might possibly show little effect as well.

Comparing the pore size distribution of the Drachenfels trachyte and the other stones used at the Cologne Cathedral, it is obvious that the Drachenfels trachyte does not have a close match (Fig. 7). The Obernkirchner sandstone has a wider distribution than the Drachenfels trachyte with $67.6 \%$ of pores $>1 \mu \mathrm{m}$, whereas the Drachenfels trachyte only has $35.1 \%$ of that range. Stenzelberg latite and Montemerlo trachyte have relatively high percentages of micropores. Londorfer basalt lava and Krensheimer Muschelkalk have an even but very unsorted pore size distribution from 0.0064 to $64 \mu \mathrm{m}$, respectively 0.0064 to $82 \mu \mathrm{m}$. The Londorfer basalt lava has $65.8 \%$ capillary pores, whereas the Krensheimer 
Muschelkalk shows $85.0 \%$. Only the Schlaitdorfer and Bozanov sandstones may be grouped as "heavy soakers"-stones with a high water absorption-with 83.3 and $89.6 \%$ capillary active pores and $47.8 \%$, respectively $68.7 \%$ pores $>10 \mu \mathrm{m}$.

Snethlage (2005) suggests using a replacement stone with a low to medium water suction value when replacing damaged parts, which originally consisted of a stone with a higher water suction value.

All the w-values of the samples are in the range from 0.3 to $6.9 \mathrm{~kg} / \mathrm{m}^{2} \cdot \sqrt{\mathrm{h}}$. The original building stone, the Drachenfels trachyte, shows a $w$ value of $0.6 \mathrm{~kg} / \mathrm{m}^{2} \cdot \sqrt{ } \mathrm{h}$. The Schlaitdorfer and Bozanov sandstones can be classified as belonging to the group of strongly absorbing stones. Montemerlo, Obernkirchner and Krensheimer are medium absorbing stones. The maximum water content attainable by capillary water uptake was not determined, since it does not play an essential role in nature. In general, the penetration depth of rain is smaller than the thickness of building components. The stones used in the Cathedral and the evaluated replacement stones show a strong divergence when considering the capillary water uptake, and thus do not meet the necessary suitability requirements (Fig. 13).

The $s$ value is a factor for the determination of the frost resistance of natural building stones. The degrees of saturation ( $s$ value) of the investigated stones are between 0.59 and 0.76 (Table 2). According to the limit value of $s<0.75$ (DIN 52103), only the Stenzelberg latite has a higher water saturation coefficient (Fig. 13).

The sorptive water uptake plays an important role in the deterioration of natural building stones due to the central European climate. The Stenzelberg latite has a very high sorptive water uptake, whereas Drachenfels and Montemerlo trachyte as well as the Londorfer basalt lava have a

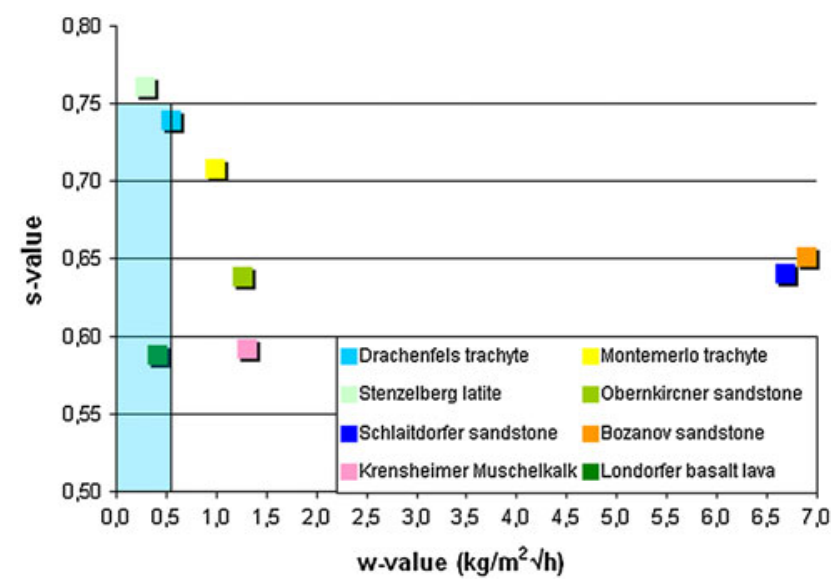

Fig. 13 Capillary water uptake ( $w$ value) and saturation degree $(s$ value) of the stones from the Cologne Cathedral show much divergence. If the proposed requirements on these two parameters are set in comparison to the Drachenfels trachyte (marked area), only the Londorfer basalt lava would show appropriate $s$ and $w$ values medium sorptive water uptake. The three sandstones and the Krensheimer Muschelkalk adsorb water only by a small degree due to their pore size distribution and the lack of a well communicating pore space. Moreover, salt contamination, e.g., due to pollution and deterioration may cause significant increases of the sorptive water uptake in exposed building stones (Kraus 1985a).

Until now, no guidelines are present to evaluate the sorptive water uptake in respect to replacement materials. Analogous to the guideline for the capillary water uptake, sorptive water uptake of the replacement stone should be the same or less as the original stone. Thus, only Stenzelberg latite does not fit into this scheme (Table 2, Fig. 14).

Since water is a driving factor for deterioration, drying processes and their length play an important role for the decay resistance. Kraus (1985a) ascertained drying durations for Schlaitdorfer sandstone of 11 days, for the Krensheimer Muschelkalk and Obernkirchner sandstone of 13 days and for the Drachenfels trachyte and the Londorfer basalt lava longer than 15 days. Krensheimer Muschelkalk shows moderate drying despite a high water vapor diffusion resistance (Kraus 1985a). The latter is determined by the low connectivity of the pores. With respect to drying, Kraus (1985a) determined that salt contamination and dirt depositions on the stone surfaces decelerate the drying process. As a requirement for replacement stones, these should dry within a moderate period. The newly inserted stone should not stay humid longer than the neighboring original one, not functioning as water supply to the latter one.

The investigated stones from the Cologne Cathedral show a broad distribution in terms of the water vapor

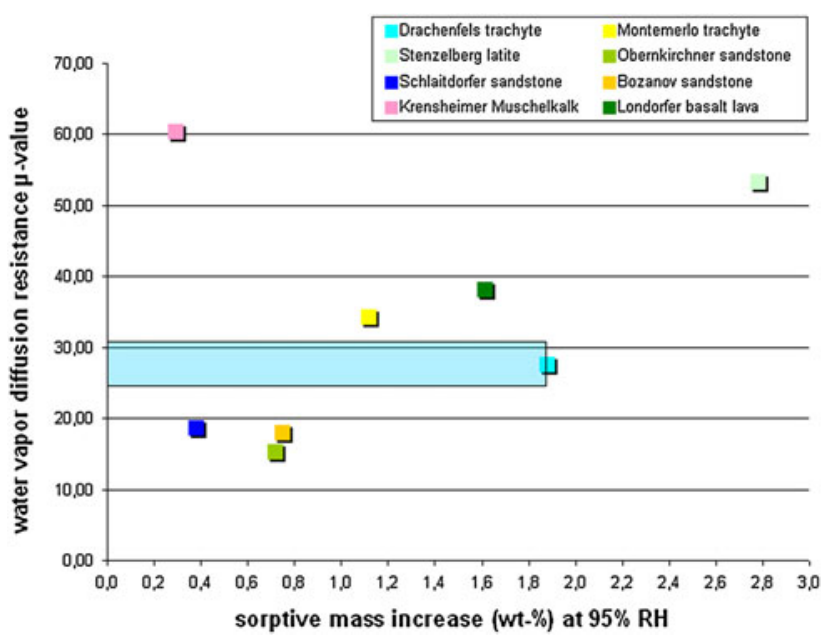

Fig. 14 Diagram showing the sorption and water vapor diffusion resistance of the investigated stones. Setting the proposed requirements in correlation to the Drachenfels trachyte (marked area), makes it clear that for one parameter, e.g., sorption, all building stones except the Stenzelberg latite might be suitable. A second parameter, the water vapor diffusion, shows the insufficient compatibility of the different stones 


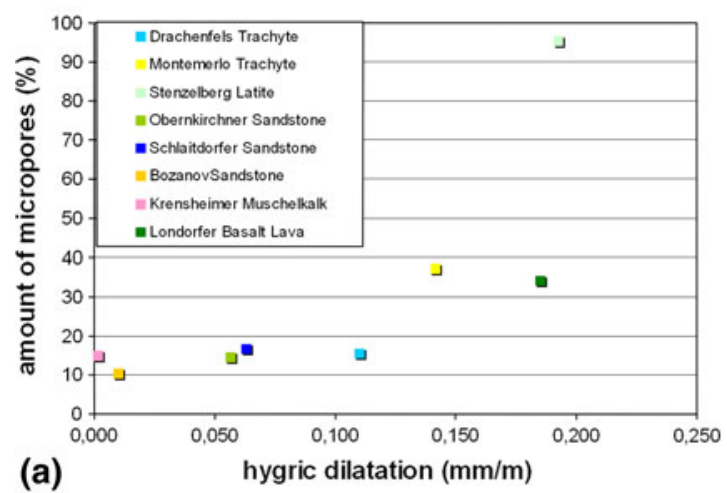

(a)

hygric dilatation $(\mathrm{mm} / \mathrm{m})$

Fig. 15 a The building stones from the Cologne Cathedral show that a higher percentage of micropores indicates stronger hygric dilatation, which again might be due to disjoining pressure in small pores. b Higher

diffusion resistance. Following the outline of a maximum divergence of $10 \%$ for the water vapor diffusion value (Snethlage 2005), it becomes obvious that the building stones at the Cologne Cathedral are not compatible with each other (Table 2; Figs. 10a, 14).

Moisture and thermal expansion are volume changes of natural building stones induced by extrinsic factors (exposition, climatic situation, and building physics). A critical hydric swelling is observed at the Montemerlo and the Drachenfels trachyte as well as the Stenzelberg latite and the Londorfer basalt lava. On the building stones from the Cologne Cathedral it can be observed, that with increasing amount of micropores hygric swelling increases as well (Fig. 15a), which indicates, that the main driving factor for moisture related length changes could be addressed to disjoining pressure in small pores. Furthermore, a smaller mean pore radius can be correlated to a

Fig. 16 Diagrams showing the strength values of the investigated stones from the Cologne Cathedral (a) uniaxial compressive strength,

(b) flexural strength and (c) tensile strength. Each have the proposed constraint of $80-120 \%$ of the original strength value (Snethlage 2001) in correlation to the Drachenfels trachyte (dark blue marked area), and widened limitations of 70-130\% (light blue marked area). Drachenfels trachyte (DT), Montemerlo trachyte (MT), Stenzelberg latite (SL), Obernkirchner sandstone (OS), Schlaitdorfer sandstone (SS), Bozanov sandstone (BS), Krensheimer Muschelkalk $(\mathrm{KM})$ and Londorfer basalt lava

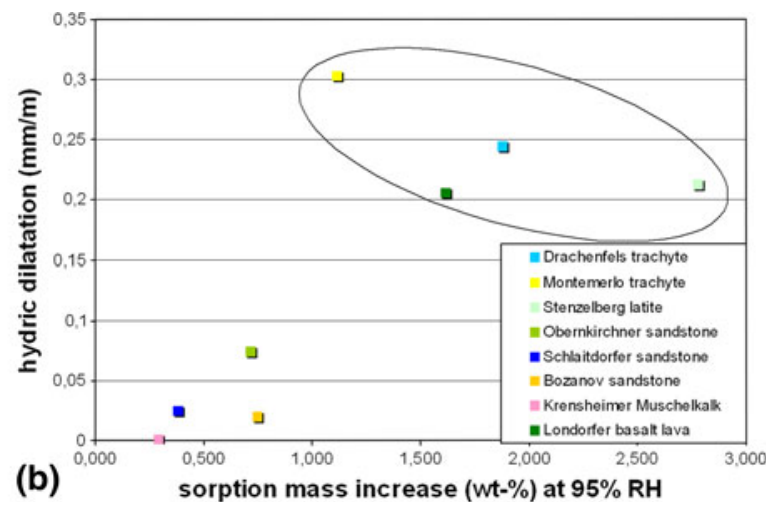

water sorption values can be correlated to higher hydric dilatation, indicating a potential damage source for Drachenfels trachyte, Stenzelberg latite, Londorfer basalt lava, and Montemerlo trachyte

higher hydric dilatation. The stones from the Cologne Cathedral with a high capillary water uptake do not necessarily show high hydric dilatation, however high sorption values can be correlated to higher hygric and hydric expansion, indicating a damage potential; as it may be interpreted for the Stenzelberg latite, Londorfer basalt lava, Montemerlo and Drachenfels trachyte (Fig. 15b).

For both moisture and thermal dilatation, lower expansion should be the aim for the replacement stones being employed. Since the investigated stones show no residual strain in terms of thermal dilatation, it is of minor importance.

In respect of strength properties, the following evaluation of the investigated stones is based on the proposed criterion of $80-120 \%$ of the strength value of the original building stone (Snethlage 2005). In respect of the uniaxial compressive strength, only the Londorfer basalt lava would be compatible in terms of the strength values to the Drachenfels

(b) flexural strength (Mpa)

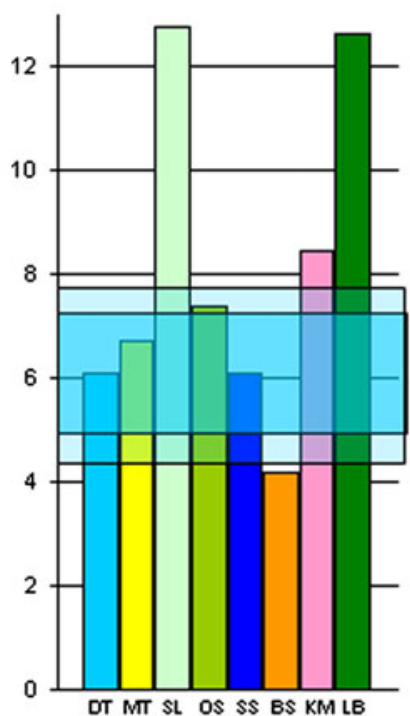

(c)

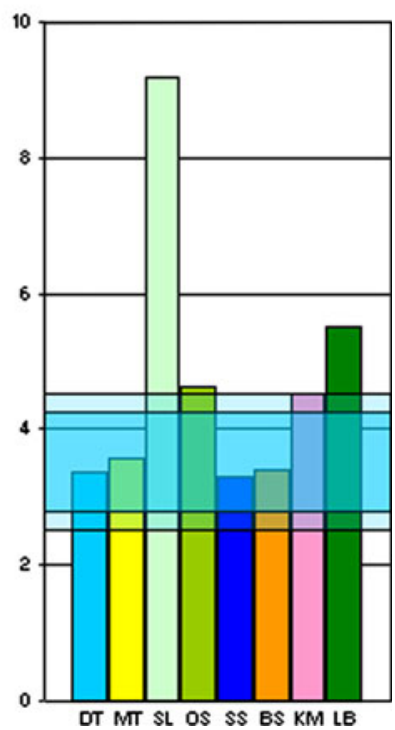


trachyte (Fig. 16a). A compatible flexural strength to the Drachenfels trachyte is shown by the Montemerlo trachyte and Schlaitdorfer sandstone (Fig. 16b). Assuming that $80-120 \%$ of the tensile strength of the original building stone would be suitable, the Drachenfels and Montemerlo trachytes as well as Schlaitdorfer and Bozanov sandstones are of one comparable range (Fig. 16c).

If the limitations are extended to $70-130 \%$, for uniaxial compressive strength all investigated stones except the Stenzelberg latite would be suitable, for flexural strength the Obernkirchner sandstone could be added. In terms of tensile strength it would be the same grouping as at 80-120\% limitation (Fig. 16).

\section{Conclusion}

The different building stones employed at Cologne Cathedral show a diverse petrography and mineralogical composition as well as a broad variety of petrophysical properties. To understand possible interactive deterioration processes it is important to determine the basic petrophysical data. The investigations described here indicate possible decay scenario and incompatibilities. The comparison with valid guidelines reveals the broad spectrum of the used materials. Moisture properties, which in turn are determined by petrophysical features, become the center of focus in terms of an evaluation of stone compatibility. A huge water exchange in the microstructure of the stone is generally correlated to a huge rise of pollutants, which not only supports a decay potential for salt and frost deterioration but also provides the necessary elements for chemical deterioration. Based on the data, a first characterization scheme for further selections of adapted stone materials for restoration purposes at the Cologne Cathedral can be predicted.

Acknowledgment This work is supported by Deutsche Bundesstiftung Umwelt. Special thanks go the colleagues of the cathedral maintenance department (Cologne Cathedral) as well as to Thomas Schumacher and master builder Barbara Schock-Werner for supporting our work. We would also like to thank Christian Gross for his help with English proofreading as well as Jörg Rüdrich, Stephan Mosch and Helmut Dürrast for their helpful comments on an earlier version.

Open Access This article is distributed under the terms of the Creative Commons Attribution Noncommercial License which permits any noncommercial use, distribution, and reproduction in any medium, provided the original author(s) and source are credited.

\section{References}

Aligizaki KK (2006) Pore Structure of Cement-Based Materials: Testing Interpretation and Requirements. Technology \& Engineering Taylor \& Francis, London, p 388
Delgado Rodrigues J, Charola AE (1996) General report on water repellents. Sci technol Cult Heritage 5:93-103

Dienemann W, Burre O (1929) Die nutzbaren Gesteine Deutschlands und ihre Lagerstätten mit Ausnahme der Kohlen, Erze und Salze. Enke, Stuttgart, p 485

DIN EN 12372 (1999) Bestimmung der Biegezugfestigkeit unter Mittellinienlast. Beuth, Berlin

DIN EN 1925 (1995) Bestimmung des Wasseraufnahmekoeffizienten infolge Kapillarwirkung. Beuth, Berlin

DIN EN 1926 (1999) Prüfverfahren für Naturstein: Bestimmung der Druckfestigkeit. Beuth, Berlin

DIN 66138 (2008) Isothermal measurement of the sorption of vapours at solids. Beuth, Berlin

DIN 52102 (1988) Bestimmung von Dichte, Trockenrohdichte, Dichtigkeitsgrad und Gesamtporosität. Beuth, Berlin

DIN 52103 (1988) Bestimmung von Wasseraufnahme und Sättigungswert. Beuth, Berlin

DIN 22024 (1989) Bestimmung der Spaltzugfestigkeit von Festgesteinen. Beuth, Berlin

DIN EN ISO 12572 (2001) Wärme- und feuchtetechnisches Verhalten von Baustoffen und Bauprodukten-Bestimmung der Wasserdampfdurchlässigkeit. Beuth, Berlin

Dombauhütte Köln (2006) Modellhafte Entwicklung von Konservierungskonzepten für den stark umweltgeschädigten Trachyt an den Domen zu Köln und Xanten. Unpubl. Report, DBU

Dunham RL (1962) Classification of carbonate rocks according to depositional texture. In: Ham WE (ed) Classification of carbonate rocks. AAPG Mem., 1, Tulsa, pp 108-121

Efes Y (1980) Wasserdampfdurchlässigkeit von unverwitterten und verwitterten Naturbausteinen. Bautenschutz Bausanierung 3(3):91-95

Efes Y, Lühr HP (1976) Natursteine am Bauwerk des Kölner Doms und ihre Verwitterung. Kölner Domblatt 41:167-194

Fitzner B, Heinrichs K, Kownatzki R (1995) Weathering formsclassification and mapping. In: Snethlage R (ed) Denkmalpflege und Naturwissenschaft, Natursteinkonservierung I. Ernst \& Sohn, Berlin, pp 41-88

Folk RL (1962) Spectral subdivision of limestone types. In: Ham WE (ed) Classification of carbonate rocks. AAPG Mem., 1, Tulsa, pp 62-84

Grimm WD (1990) Bildatlas wichtiger Denkmalgesteine der Bundesrepublik Deutschland. Arbeitsheft des Bayerischen Landesamtes für Denkmalpflege, Bd. 50, München, p 655

Grün R (1931) Die Verwitterung von Steinen. In: Die Denkmalpflege 33 (1931), pp 168-180

Grün R (1933) Verwitterung der Bausteine vom chemischen Standpunkt. In: Chemikerztg. 57:401-403

Hertel B (1927) Die Wiederherstellungsarbeiten am Kölner Dome. In: Der Kölner Dom in Gefahr, pp 39-91

Hirschwald J (1910) Die Bautechnisch verwertbaren GesteinsVorkommnisse des Preussischen Staates u. einiger Nachbargebiete. Kgl. Ministeriums d. öffentl. Arbeiten. Bornträger, Berlin

Hirschwald J (1912) Bautechnische Gesteinsuntersuchungen: Mitlg. Mineralog.-geolog. Institut d Kgl. Techn. Hochschule Berlin. Jg.1.1910-Jg.3. Bornträger, Berlin

Kaiser E (1910) Wetterbeständigkeit einer Reihe von Kalksteinen mit besonderer Berücksichtigung der Verhältnisse am Cölner Dom. Unpupl. report, Gießen

Kaiser E (1910a) Bericht über die Versuche der Verwitterung von vulkanischen Tuffen und eines Trachyts vom Drachenfels in der schwefelsauren Atmosphäre. Unpupl. report, Gießen

Kaiser E (1910b) Angewandte Methode der Prüfung der Wetterbeständigkeit nebst Vorschlägen zu einem weiteren Ausbau dieser Methodik. Unpupl. report, Gießen

Klopfer H (1985) Feuchte. In: Lutz P et al (eds) Lehrbuch der Bauphysik. Teubner, Stuttgart, pp 329-472 
Knacke-Loy O (1988) Verwitterungsdifferenzierungen von Stubensandstein-Bauteilen des Kölner Doms. University of Tübingen, Germany

Knacke-Loy O (1989) Der Schlaitdorfer Sandstein und seine unterschiedliche Verwitterungs-anfälligkeit am Kölner Dom. Kölner Domblatt 54:61-72

Knetsch G (1952) Geologie am Kölner Dom. Int J Earth Sci 40(1):57-73

Koch R (2000) Vergleichende petrographische Untersuchung an Sandsteinen aus dem Steinbruch Pliezhausen und einem tschechischen Sandstein. Unpubl. report. University of Erlangen, Nürnberg

Koch R (2001) Zur Geologie und Fazies eines Sandsteins aus Nordost-Tschechien (Gebiet um Bozanov-Teplice-Police). Unpubl. report. University of Erlangen, Nürnberg

Koch R (2006) Trachyte aus dem Colli Euganei, Norditalien. In: Dombauhütte Köln (2006) Modellhafte Entwicklung von Konservierungskonzepten für den stark umweltgeschädigten Trachyt an den Domen zu Köln und Xanten. Unpubl. report, DBU, pp $9-42$

Koch A, Siegesmund S (2001) Gesteinstechnische Eigenschaften ausgewählter Bausandsteine. Z dt Ges Geowiss 152:681-700

Kraus K (1980) Verwitterungsvorgänge an Bausteinen des Kölner Doms: ein Beitrag zur Proble-matik der Naturstein-Verwitterung an Bau-Denkmälern im Stadtklima/Köln. University of Cologne, Cologne, p 112

Kraus K (1985) Experimente zur immissionsbedingten Verwitterung der Naturbausteine des Kölner Doms im Vergleich zu deren Verhalten am Bauwerk. Dissertation, University of Cologne, p 208

Kraus K (1985b) Unterschiedliche Witterungsanfälligkeit der Kölner Dombausteine. Kölner Domblatt 50:101-104

Kraus K, Jasmund K (1981) Verwitterungsvorgänge an Bausteinen des Kölner Domes. Kölner Domblatt 46:175-190

Lazzarini L, Antonelli F, Cancelliere S, Conventi A (2008) The deterioration of Euganean trachyte in Venice. 11th Int. Congr. Deterioration and Conservation of Stone. Nicolaus Copernicus Univ. Torun, Poland, pp 153-162

Luckat S (1973a) Ein Schnelltestgerät zur Prüfung von Resistenzverhalten mineralischer Baustoffe gegenüber Luftverunreinigungen. Dt. Kunst- und Denkmalpflege 31:51-53

Luckat S (1973b) Die Einwirkung von Luftverunreinigungen auf die Bau-subs-tanz des Kölner Domes. Teil I. Kölner Domblatt 36(37):65-74

Luckat S (1974) Die Einwirkung von Luftverunreinigungen auf die Bau-subs-tanz des Kölner Domes. Teil II. Kölner Domblatt 38(39):95-106

Luckat S (1975) Die Einwirkung von Luftverunreinigungen auf die Bau-subs-tanz des Kölner Domes. Teil III. Kölner Domblatt 40:75-108

Luckat S (1977) Die Einwirkung von Luftverunreinigungen auf die Bau-subs-tanz des Kölner Domes. Teil IV. Kölner Domblatt 42:151-175

Luckat S (1984) Beton, Stein und Eisen bricht. In: Dankwart, Guratzsch (eds) Baumlos in die Zukunft. Kindler, München, pp 225-237

Lasaulx A von (1882) Die Bausteine des Kölner Domes, Bonn

Mirwald P, Kraus K, Wolff A (1987) Stones of the Cathedral of Cologne and their damages. Ms. University Dortmund, Germany

Morales Demarco M, Jahns E, Rüdrich J, Oyhantcabal P, Siegesmund $S$ (2007) The impact of partial water saturation in rock strength: an experimental study on sandstone. $\mathrm{Z}$ dt Ges Geowiss 158(4):869-882

Mosch S (2008) Optimierung der Exploration, Gewinnung und Materialcharakterisierung von Naturwerksteinen. Dissertation, University of Göttingen, p 277
Nussbaum N, Lepsky S (2010) Intermediate report on the building historical survey. Colloquium Cologne Cathedral, Nov 2010

Peschel A (1983) Natursteine. VEB Dt. Vlg. Grundstoffindust., Leipzig, p 448

Přikryl R, Weishauptová Z, Novotná M, Přikrylová J, Št'astná A (2010) Physical and mechanical properties of the repaired sandstone ashlars in the facing masonry of the Charles Bridge in Prague (Czech Republic) and an analytical study for the causes of its rapid decay. Environ Earth Sci. doi:10.1007/s12665010-0819-5

Rathgen F, Koch J (1934) Verwitterung und Erhaltung von Werksteinen: Beiträge zur Frage der Steinschutzmittel. Zement \& Beton, Berlin, p 122

Rüdrich J, Siegesmund S (2006) Salt and ice crystallisation in porous sandstones. Environ Geol. doi:10.1007/s00254-006-0585-6

Rüdrich J, Kirchner D, Seidel M, Siegesmund S (2005) Beanspruchungen von Naturwerksteinen durch Salz- und Eiskristallisation im Porenraum sowie hygrische Dehnungsvorgänge. Z dt Ges Geowiss 156(1):59-73

Ruedrich J, Bartelsen T, Dohrmann R, Siegesmund S (2010) Moisture expansion as a deterioration factor for sandstone used in buildings. Environ Earth Sci. doi:10.1007/s12665-010-0767-0

Ruedrich J, Kirchner D, Siegesmund S (2010b) Physical weathering of building stones induce by freeze-thaw action: a laboratory long-term study. Environ Earth Sci. doi:10.1007/s12665010-0826-6

Scheuren E (2004) Kölner Dom und Drachenfels. In: Schock-Werner und Lauer (eds) Steine für den Dom. Kölner Dom, pp 22-45

Schumacher T (2004) Steine für den Dom. In: Schock-Werner und Lauer (eds) Steine für den Dom. Kölner Dom, pp 46-77

Siedel H, Siegfried S, Sterflinger K (2011) Characterization of Stone deterioration on buildings. In: Siegesmund, Snethlage (eds) Stone in architecture, 4th edn. Springer, Berlin, pp 347-410

Siegesmund S, Dürrast H (2011) Physical and mechanical properties of rocks. In: Siegesmund, Snethlage (eds) Stone in architecture, 4th edn. Springer, Berlin, pp 97-225

Siegesmund S, Snethlage R (2011) Stone in architecture, 4th edn. Springer, Berlin, p 552

Siegesmund S, Török A, Hüpers A, Müller C (2007) Mineralogical, geochemical and microfabric evidences of gypsum crusts: a case study from Budapest. Env Geol 52:385-397

Siegesmund S, Grimm WD, Dürrast H, Rüdrich J (2010) Limestones in architecture: the German view. In: Smith B, Gomez-Heras M, Viles H, Cassar J (eds) Limestone in the built environment: present day challenges to preserve the past, vol 331. Geol Soc Spec, London, pp 37-59

Snethlage R (1984) Steinkonservierung 1979-1983. Report Volkswagenstiftung. Bayer. LAD, Munic, p 203

Snethlage R (2005) Leitfaden Steinkonservierung. Fraunhofer IRB, Stuttgart, p 289

Steindlberger E (2003) Vulkanische Gesteine aus Hessen und ihre Eigenschaften als Naturwerksteine. Geologische Abhandlungen Hessen, Band 110, Wiesbaden

Stück H, Forgó Z, Rüdrich J, Siegesmund S, Török A (2008) The behaviour of consolidated volcanic tuffs:weathering mechanisms under simulated laboratory conditions. In: Siegesmund S, Snethlage R, Ruedrich J (eds) Monumental future:climate change, air pollution, stone decay and conservation. Environmental Geology 56:699-713. doi:10.1007/s00254-0081337-6

Török A, Licha T, Simon K, Siegesmund S (2010) Urban and rural limestone weathering; the contribution of dust to black crust formation; examples from Germany and Hungary. Environ. Earth Sci. doi:10.1007/s12665-010-0737-6

van Brakel J, Modry S, Svata M (1981) Mercury porosimetry: state of the art. Powder Technol 29:1-12 
von Plehwe-Leisen E, Leisen H, Wendler E (2007) Der DrachenfelsTrachyt-ein wichtiges Denkmalgestein des MittelaltersUntersuchungen zur Konservierung. $\mathrm{Z}$ dt Ges Geowiss 158(3):985-998

Weiss T, Siegesmund S, Kirchner D, Sippel J (2004) Insolation weathering and hygric dilatation as a control on building stone degradation. Env Geol 46(3-4):402-413

Wesche K (1996) Baustoffe für tragende Bauteile Grundlagen 1. Bauverlag, Wiesbaden, p 145

Windscheid A (2004) Steine für den Dom. In: Schock-Werner und Lauer (ed) Steine für den Dom. Kölner Dom

Wolf C (2002) Urban air pollution and health: an ecological study of chronic rhinosinusitis in Cologne, Germany. Health Place 8:129-139

Wolff A (1986) Stone deterioration on the Cathedral of Cologne: Paper, presented at the Symposium "Air Pollution and Conservation", Rome
Wolff A (1992) Dombaubericht von Oktober 1991 bis September 1992: 10.1 Londorfer Basaltlava und Schlaitdorfer Sandstein. Kölner Domblatt 57:89-93

Wolff A (2004) Steine für den Dom. In: Schock-Werner und Lauer (ed) Steine für den Dom. Kölner Dom, pp 8-21

Wolff A, Luckat S (1973) Untersuchungen zur Einwirkung von Luftverunreinigungen auf die Bau-materialien des Kölner Domes. Proceedings of the third International Clean Air Congress. VDI-Verlag, Düsseldorf, pp A90-A92

Wolff A, Mirwald PW, Kraus K (1988) Stone deterioration on the Cathedral of Cologne. In: Durability of building materials. 5:549-570

Zeisig A, Siegesmund S, Weiss T (2002) Thermal expansion and its control on the durability of marbles. Geol Soc Spec Publ 205:64-79 